\title{
Research Article Playing with Fire: Internal Devaluation for the GIPSI Countries
}

\author{
David Peón ${ }^{1}$ and Fernando Rey ${ }^{2}$ \\ ${ }^{1}$ BBVA Group and Department of Finance and Accounting, University of A Coruña, Campus Elviña s/n, 15071 A Coruña, Spain \\ ${ }^{2}$ Department of Applied Economics, University of A Coruña, Campus Elviña s/n, 15071 A Coruña, Spain
}

Correspondence should be addressed to David Peón; davidpeon@gmail.com

Received 3 June 2013; Accepted 29 June 2013

Academic Editors: B. M. Tabak and E. Yeldan

Copyright (@ 2013 D. Peón and F. Rey. This is an open access article distributed under the Creative Commons Attribution License, which permits unrestricted use, distribution, and reproduction in any medium, provided the original work is properly cited.

\begin{abstract}
European authorities are encouraging internal devaluation by GIPSI countries in order to improve their competitiveness and reduce current account deficits. However, this option introduces an additional source of risk, as it may generate deflation, making fiscal consolidation for these countries even harder to achieve. Several authors have suggested that an enhanced coordination of national fiscal policies would be preferable. This paper contributes to the debate in two instances. First, we analyze the main drivers of debt dynamics for peripheral versus core countries in the Eurozone in the last decade, to evidence that GIPSI countries should focus on a fiscal consolidation that does not damage growth, while deflation should be avoided. Second, we implement a scenario analysis to analyze the effectiveness of a coordinated policy among Eurozone members, where core countries accept a 3\% target for inflation and reduce the pace of their fiscal consolidation, while GIPSI countries focus on fiscal consolidation with a low (but positive) level of inflation. This coordinated policy might be a better option as it (i) increases the competitiveness of GIPSI countries while avoiding the risks of deflation, (ii) ensures stability of debt for both groups of countries without imposing an excessive inflation target from EU core countries, and (iii) introduces the possibility of a fiscal stimulus.
\end{abstract}

\section{Introduction}

The sovereign debt crisis in the Eurozone is perhaps the main source of concern on the road to secure global economic recovery and restoring financial stability [1]. The global economic crisis resulted in a large deterioration of fiscal accounts in most advanced economies, being particularly significant for the peripheral countries in the Eurozone (namely, Greece, Ireland, Portugal, Spain, and Italy, a.k.a. GIPSI countries). Fiscal imbalances and debt levels were then aggravated by the expansionary policies implemented at the first stage of the crisis to provide support for aggregate demand and to aid the financial sector.

Several authors (e.g., Abbas et al. [2]) warned at that time on the necessity of correcting fiscal imbalances and reducing public debt, and this has been a priority for European authorities since the outburst of the euro crisis. However, austerity policies are leading GIPSI countries to a deep recession, when not to a depression. The debate about fiscal austerity versus economic growth is bitter now, with no consensus about which policy would be better to achieve a fiscal balance while not jeopardizing economic growth. For instance, the recent IMF WEO $[3,4]$ intensified the debate when it attributed contractionary effects to fiscal austerity, while European authorities-led by countries like Germany-remain the strongest advocates of potential benefits of the fiscal policies implemented so far.

A motivation to write this paper has been that research papers and economic policies often tend to observe the deleverage process and alternatives for fiscal consolidation on a case by case basis. However, this strategy is no longer valid in the context of the sovereign debt crisis in the Eurozone, under an institutional framework where all member countries have ceded part of their sovereignty and where national economic policies are limited due to this institutional setting. Hence, an enhanced coordination of national fiscal policies would be preferable [5]. Some authors (e.g., Schmitt-Grohé and Uribe [6]) have indeed suggested that it is unlikely that a solution 


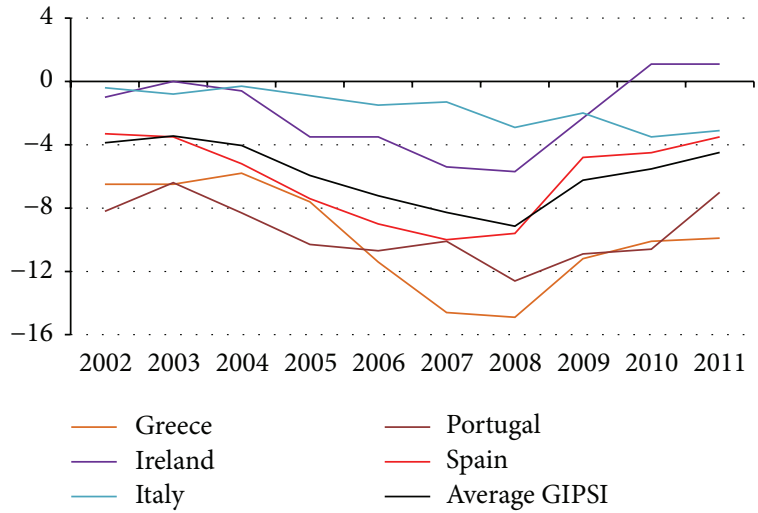

FIgURE 1: Current account to GDP, GIPSI countries. Source: own elaboration, data from Eurostat.

will come from within national borders: a supranational monetary stimulus (i.e., higher inflation) would be required to solve the crisis.

This approach becomes necessary when some of the causes and effects of the crisis for EU core (creditor) and peripheral (debtor) countries are two sides of the same coin. In particular, some authorities suggest internal devaluation is a desirable policy for GIPSIs. When a debt crisis triggered in countries with a currency of their own-like several episodes of emerging countries in the past-a classic solution was that the IMF financed the country and imposed fiscal consolidation and devaluation, combined with an expansionary monetary policy. For Eurozone members this is not possible since the monetary policy has been transferred and the option for national currency devaluation has been switched off. Hence, authorities suggest a "second best" option would be internal devaluation through wage cuts. This is what GIPSI countries are doing in order to improve competitiveness and reduce current account deficits.

However, this option introduces an additional source of risk: in the midst of a credit crisis and with the country having no access to devaluation, fiscal consolidation generates deflation [7]. As some authors have warned (see [8]), this may be a dangerous strategy in a context where the private sector is heavily indebted and currently ongoing a necessary process of deleveraging. Governments would have higher ability to make public debt sustainable in a context of high growth and moderate inflation. In particular, our purpose in this paper is to analyze how internal devaluation might only make fiscal consolidation even harder to achieve.

Our contribution in this paper is twofold. First, we analyze the main drivers of changes in debt of peripheral versus core countries in the Eurozone, before and after the financial crisis. Second, we introduce a scenario analysis in order to forecast the effectiveness of different fiscal policies. In particular, we show how a coordinated policy might be the best option, since (i) it increases the competitiveness of GIPSI countries by setting a higher inflation target in the core and lower-but positive, avoiding deflation-in the periphere; (ii) it reduces the size of the required fiscal consolidation that ensures the sustainability of debt under different scenarios of low inflation versus deflation; (iii) EU core countries might easily accept this inflation target, which ensures debt remains stable as long as they keep moderate levels of PSR. This combined policy would set a more suitable scenario for fiscal consolidation of GIPSIs to succeed, helping to solve the euro crisis and hence benefiting both peripheral and core countries.

The rest of the paper is organized as follows. Section 2 describes the European sovereign crisis and some strategies to solve it that have been proposed. In Section 3 we describe the sample and methodology of our research. In Section 4 we analyze the debt dynamics in the Eurozone, both on a country-by-country basis and by comparing EU core versus GIPSI countries. Section 5 includes a forecast to compare an isolated versus a coordinated economic policy for Eurozone members. Finally, Section 6 concludes.

\section{The European Sovereign Debt Crisis}

There is now a large consensus that the institutional design of the euro was a major factor behind the sovereign crisis in the Eurozone, both because it increased fiscal risks during the precrisis period and because it amplified the fiscal impact once the crisis occurred. According to Lane [5], with the benefit of hindsight, 1999-2007 was a period in which growth masked the accumulation of several macroeconomic, financial and fiscal vulnerabilities, including strong credit booms and the persistence of huge current account imbalances (see Figure 1).

Beyond the institutional flaws of the Eurozone, three initial conditions that explain the spread and severity of the crisis [10] were that banks entered the crisis with low levels of capital and high risk exposure, that major sovereigns did not accumulate adequate fiscal buffers prior to the crisis, and the unprecedented degree of interconnectedness in the global financial system. The lessons of history (see [11]) show that these episodes tend to follow a predictable pattern, where the rises in private debts are a recurring antecedent to banking crises, which often precede or accompany sovereign debt crises, which in turn accelerate due to "hidden debts" faced by public authorities-particularly private debt that becomes public as the crisis unfolds.

The Eurozone sovereign crisis was not an exception. Mody and Sandri [12] suggest the Eurozone sovereign and banking crisis unfolded in three phases. In the first one, global financial stress was transmitted to Europe following the onset of the subprime crisis in July 2007. Then, since the rescue of Bear Stearns in March 2008, oddly enough a distinctive European dimension of the banking crisis emerged. The final phase starts with the nationalization of Anglo Irish in January 2009 because it represented to be a European marker on one hand and because the limits of fiscal support for domestic banks started to become clearer on the other-so a sovereign crisis started.

An exception was, however, that the role the design flaws of the euro had in amplifying the fiscal impact, while the restrictions imposed by the monetary union also amplified the duration of the postcrisis recovery. These design problems 
would include [5] the low capacity of euro-member countries to withstand negative macroeconomic and financial shocks, the free-rider problems that appear when national governments can borrow in a common currency and there are strong incentives to bail out a country that borrows excessively [13], and the fact that the lack of a banking union made individual governments to carry the risks of a banking crisis.

The main result of the crisis has been a historically high and rising level of public indebtedness of most European countries. Reinhart et al. [14] note several sources of concern for this situation. First, once a public debt overhang has lasted five years, it is likely to last 10 years or much more (the average duration of debt episodes was 23 years). Second, public debt in most advanced economies is projected to keep on rising over the next decade or two. Third, most economies are facing a "quadruple debt overhang" of public, private, external, and pension debt, aggravated by the emergence of "hidden debts" in the public sector mentioned above. Finally, the burden of debt tends to reduce the rate of GDP growth. Recently there has been much controversy about this topic. Reinhart and Rogoff [15] provided empirical evidence that debt-toGDP ratios above $90 \%$ are correlated with growth rates one percentage point lower than average. Firstly, some authors (e.g., Panizza and Presbitero [16]) disagreed on the nature of the causal effect of this correlation, suggesting it may be slow economic growth what leads to debt accumulation and not the other way around. However, it was a paper by Herndon et al. [17] that spurred controversy. The authors replicated Reinhart and Rogoff's empirical analysis to find that "coding errors, selective exclusion of available data, and unconventional weighting of summary statistics lead to serious errors that inaccurately represent the relationship between public debt and GDP growth."

The necessity of correcting fiscal imbalances and reducing public debt is clear, but there is a bitter debate regarding how to achieve that goal. The key is in the analysis of public debt dynamics. The classic framework is the golden rule of longterm debt sustainability, which states that for the debt-toGDP ratio to hold stable the primary surplus ratio, PSR, must be equal to or higher than the debt-to-GDP ratio multiplied by the difference between the nominal interest rate paid on the debt, $i$, and GDP's annual nominal growth rate, $g$. Formally,

$$
\mathrm{PSR} \geq \frac{D}{\mathrm{GDP}} \times(i-g) .
$$

Table 1 shows the situation as of 2012 for the main countries in the Eurozone, United Kingdom, United States, and Japan, according to Antelo and Peón [8]. All countries except Germany fail to fulfill the required fiscal balance.

The recent "The good, the bad and the ugly" report [3] uses a dynamic interpretation of that golden rule to analyze episodes that begin when public debt rises above $100 \%$ of GDP, in order to see what happened after different policies were implemented. The results observed stress the role of primary surplus, interest rates, inflation, and growth in achieving fiscal consolidation. First, debt reduction ultimately requires primary surpluses. GIPSI countries must focus on reducing deficits, but only as long as this does not damage growth: high growth has reduced debt when hyperinflation episodes are excluded. Second, hyperinflation is clearly associated with sharp debt reduction, but this is obviously not a desirable strategy. When hyperinflation episodes are excluded, the only clear association between inflation and debt would be that no deflation episodes have been associated with a debt reduction. The IMF report stresses the lessons about fiscal austerity and the difficulties created by deflation in the UK 1918 and Japan 1997 episodes. Third, the difference between the real interest rate and the real GDP growth plays a crucial role. The high risk premia markets impose on GIPSI countries make higher nominal growth rates desirable. However, it is not a surprise that a weak economic growth is expected in these countries for years to come.

Doubts about fiscal sustainability of the GIPSIs have raised several concerns, in particular that governments will use inflation in order to achieve fiscal solvency [18]. However, other authors suggest on the contrary that accepting a higher inflation target would be an effective strategy. Well-known defenders include Rogoff [19], Krugman [20], and Stiglitz [21] — though critics to this idea are also manifold (e.g., [22]). According to this view, the adjustment is easier to be done by creditor countries if they accept a real appreciation of their economies rather than making their trading partners depreciate theirs, since a moderate level of inflation is easier to achieve than an equivalent level of deflation [21]. Andrés [23] explains pros and cons: we must moderate costs but accept a higher inflation if it is associated with a stronger demand. For this strategy to be safe, we should control the risk of losing credibility and of anchoring expectations in the future. Both Andrés [23] and Schmitt-Grohé and Uribe [6] estimate that a required inflation target about $4 \%$ for the next five to ten years would restore full employment in peripheral Europe. Similarly, Aizenman and Marion [24] calculate a rate of $5 \%$ to stabilize US public finances.

In this paper we suggest an alternative that may satisfy both points of view. We first analyze the effects of different factors over the dynamics of debt for Eurozone members in the past. In particular we pay attention to the effects of inflation/deflation and the possibility for a coordinated policy to help solving the crisis. Then, we conduct a scenario analysis to check whether a coordinated policy that includes an inflation differential between EU core and GIPSI countries might be helpful. This on one hand would avoid the perils of deflation on GIPSI, as it would only impose a heavier burden for fiscal sustainability. On the other hand, the inflation goals required to core countries would be quite prudential, since we use a $3 \%$ inflation target for our estimates. This coordinated policy satisfies the evidence in IMF [3], while it would require an inflation level for EU core members only one percentage point above ECB's target.

Internal devaluation might be a worst solution. Wages falling would make private sector indebtedness even worst. If it also creates deflation that would be harmful for consolidation purposes. Our approach might be supported by recent results by Faraglia et al. [18], who show that the relevance of inflation in driving the fiscal balance strongly depends on the institutional environment. While inflation plays a 
TABLE 1: Public debt barometer for several countries in 2012.

\begin{tabular}{lcccc}
\hline & PSR 2011 & (1) PSR 2012(f) & $(2)($ Debt/GDP $) \times(i-g)$ & -0.2 \\
Germany & 1.6 & 1.0 & 4.5 & $-(2)$ \\
Italy & 1.0 & 3.0 & 0.5 & -1.5 \\
France & -2.6 & -2.2 & -1.9 & -2.7 \\
U.S.A. & -7.3 & -6.1 & -1.0 & -4.2 \\
United Kingdom & -5.0 & -5.3 & 3.9 & -4.3 \\
Spain & -6.1 & -3.6 & -1.3 & -7.5 \\
Japan & -9.1 & -8.9 & 5.1 & -7.6 \\
Ireland & -6.7 & -4.4 & 9.9 & -9.5 \\
Portugal & -0.4 & 0.1 & 41.4 & -42.8 \\
Greece & -2.2 & -1.0 & & \\
\hline
\end{tabular}

Source: Antelo and Peón [8].

modest role in achieving fiscal sustainability under optimal (coordinated) policy, when monetary and fiscal policies are conducted by separate authorities inflation becomes essential in making the debt level manageable.

\section{Sample and Methodology}

Eleven euro members have been considered for our research: Austria, Belgium, Finland, France, Germany, Greece, Ireland, Italy, the Netherlands, Portugal, and Spain. This implies the largest eleven members in terms of GDP (their GDP represented about $98.0 \%$ of EU-17 GDP in 2011, according to IMF [3] database). We split them into two groups. Creditor countries on one hand (from now "EU core" countries), which include Austria, Belgium, Finland, France, Germany, and The Netherlands, and debtor countries (from now GIPSI countries) on the other, including Greece, Ireland, Italy, Portugal, and Spain. This division emphasizes one of the major factors behind the euro crisis: most creditor countries exhibited large and continued current account surpluses before 2008 (and most of them continued that performance during the years after the crisis); debtor countries, on the contrary, all experienced large and unsustainable deficits, as we saw in Figure 1. (The only exception here would be France, which runs increasing deficits since year 2006.) Beyond that, the most relevant factor to split them this way is obviously that peripheral countries have been granted any sort of bailout, either they are in the spotlight for future rescue plans (by the end of 2012 Italy was the only country of the five to be able to avoid any sort of bailout, since Spain has already accepted a rescue plan for its financial sector), or they are enduring high risk premia in sovereign debt markets—unlike EU core countries.

We conduct two types of research, an analysis of debt dynamics based on historical data and a forecast for different policy strategies. Hence, the time horizon considered includes two periods: from 2004 to 2012 for the historical analysis (Section 4) and from 2013 to 2022 for the forecast (Section 5). In order to analyze the dynamics of debt before and after the triggering of the financial crisis, the historical analysis is split into two periods: the performance during the years before (2004-2007, from now P1) and after the crisis
(2008-2012, from now P2). As a framework for analyzing the evolution of debt-to-GDP ratios we use the dynamic interpretation of the "golden rule of debt" (see [3] for a description), given by

$$
D_{t}=\frac{1+i_{t}}{\left(1+\pi_{t}\right) \times\left(1+g_{t}\right)} \times D_{t-1}+\mathrm{PDR}_{t}+e_{t},
$$

where $D_{t}$ is the level of debt in period $t, i_{t}$ denotes interest rate, $\pi_{t}$ is the inflation rate of the GDP deflator, $\mathrm{PDR}_{t}$ is the primary deficit ratio (we may alternatively use $\mathrm{PSR}_{t}$ with a negative sign), and $e_{t}$ is a residual that takes into account valuation effects and other accounting adjustments not fully captured by changes in the primary deficit. The other variables are similar to those in (1), with $i_{t}$ here being in nominal terms and $g_{t}$ in real terms. The decomposition of debt dynamics is based on a linearized version of (2).

We retrieve data from Eurostat, IMF [9], and ECB Statistical Data Warehouse (SDW). Readers may find open access to data and estimations available at http://www .dpeon.com/documentos.html. From Eurostat we retrieve "GDP and main components-price indices" for GDP deflator (as inflation) and "real GDP growth rate-percentage change on previous year" for GDP growth. From Eurostat and IMF [9], we use annual data of "general government gross debt in percentage of GDP" for debt levels. From ECB SDW and IMF [9] we retrieve "primary deficit or surplus to GDP" neither seasonally nor working day adjusted. Finally, as a general proxy for the cost of debt we use the interest rates for ten-year bonds in secondary markets, also retrieved from ECB SDW. We retrieve monthly data (average of observations through period) from ECB and estimate the annual averages in order to obtain a time series of 10year interest rates for each country. We later explain we changed this proxy for those countries that accepted a bailout (namely, Greece, Ireland, and Portugal), as market rates were no longer representative of their cost of debt. Readers may note the use of these proxies introduces an additional source of volatility for residuals-beyond valuation effects and other accounting adjustments not fully captured by changes in the primary deficit (see [3]). However, a perhaps more relevant source comes from the banking bailouts most countries have performed, as we shall see next. 


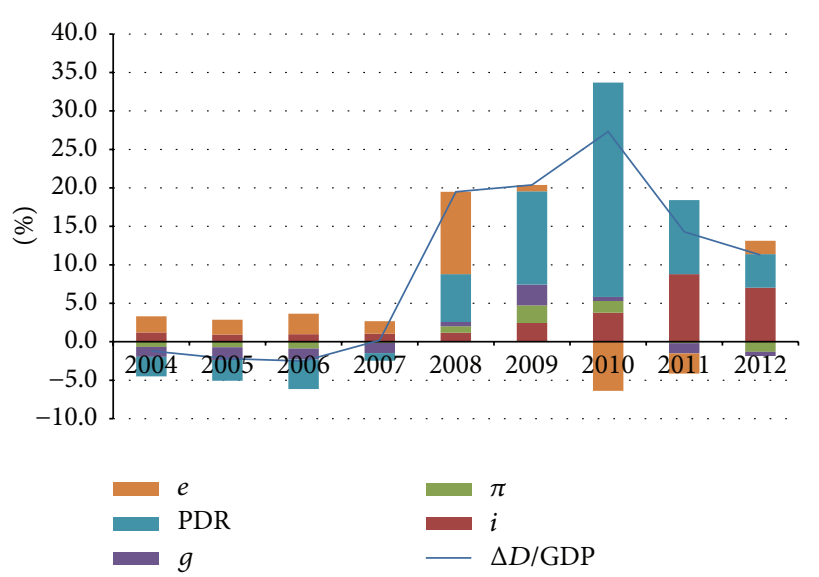

FIgURE 2: Debt dynamics: Ireland. Source: own elaboration, data from IMF [9], Eurostat, and ECB SDW.

\section{Debt Dynamics in the Eurozone}

In this section we analyze how these factors explain the evolution of debt-to-GDP ratios. We do this in two instances. First, on a country-by-country basis, in order to mention the main results observed for each country. Second, in what constitutes a key objective in this paper, we analyze the different dynamics of debt between GIPSI and EU core countries, in order to draw conclusions of interest for our forecast in Section 5.

4.1. Country Analysis. We perform a first decomposition of debt dynamics from 2004 to 2012 for each country in the sample, following the description in Section 3, using 10-year bonds interest rates in secondary markets as a proxy for the cost of debt. Original data and figures for all countries are available in Figures 3, 4, 5, 6, 7, 8, 9, 10, 11, 12, and 13 throughout the text. In Figure 2 we may see the decomposition of Irish debt as an example. The solid line represents the total increase in debt-to-GDP ratios year over year. Each bar represents the decomposition of such debt increases (or decreases) each year, with different colours denoting different factors in (2). It is easy to distinguish the effect of each factor in the evolution of debt-to-GDP ratio over the years. For instance, in the case of Ireland we may see the largest driving factor for the increasing levels of debt since 2008 has been the primary deficit PDR, followed by the cost of debt, $i$.

For most countries, several years (mainly in sample P2) show residuals that are significant. Beyond the classic valuation effects and accounting adjustments in the primary deficit and the use of 10-year bond interest rates as a proxy for the cost of debt, some residuals are particularly large due to the banking (most countries) and sovereign bailouts (in the case of Greece, Ireland, and Portugal) performed since 2008. Consequently, we make two additional considerations. First, as banking bailouts are an exogenous factor to our framework in (2), we make no adjustments here and only remark these episodes for each country when appropriate. In particular we note the effects of the European bank bailout program in October 2008 (see [25] for more information), which concerned the largest countries in the Eurozone, plus the most significant bailout episodes. These included among others the Irish supporting of its banking sector in September 2008, the nationalization of ABN Amro, Fortis Bank in 2008 and Dexia in 2011 by the governments of the Benelux and France, or the nationalization of Bankia and other savings banks in 2012 by the Spanish authorities. Second, sovereign bailouts make our estimations for the cost of debt of Greece, Ireland, and Portugal based on market rates particularly misleading. Hence, only for these three countries we have reestimated their debt dynamics using an estimation of the interest rates agreed to pay in the different rescue plans. Please see the Appendix for a clarification of how the new interest rates were estimated. These are the main results of the analysis on a country basis.

Austria. Debt-to-GDP ratios have remained quite stable during the last decade, with the exception of a $9 \%$ increase within 2008-2009. The main drivers of this good performance have been inflation and growth rates, with the only exception of year 2009. The effects of the crisis are also noticeable in the impact of PDR over debt-to-GDP ratios since 2009, and the effects of the bank bailout program in the residual of year 2008.

Belgium. The burden of debt was reduced about 15 percent until 2007 , only to return to debt ratios about $100 \%$ of GDP by 2012 , mostly as a consequence of bank bailouts in 2008in which Fortis and Dexia received $€ 4.7$ billion and $€ 3$ billion of public funds, respectively-and fiscal and growth deterioration in 2009. Notwithstanding, since 2010 Belgium is showing a better performance, particularly in terms of growth and PSR-which is now positive.

Finland. Data shows the effects of the economic cycle over debt-to-GDP ratios, especially manifested in the strong deterioration of PSR (+4.65 in 2007 versus -3.35 in 2009), being the main driver of debt dynamics. Public finances are now in a path to recovery, however the predicted deterioration in year 2012. Other significant drivers have been growth, which has supported debt stability with the only exception of year 2009, and an increasing positive effect of inflation since 2007.

France. With the only exception of 2006, debt-to-GDP ratios have been increasing all over the period. The deterioration of public finances in 2008 and 2009 has been corrected only partially. As a consequence, the main driver of the weak debt performance has been PDR. It is also noticeable the effects of the bank bailout program over the residual term in 2008 and the negative GDP rate of 2009.

Germany. Despite the good macroperformance and the decreasing cost of debt Germany is facing, debt ratios have increased almost 20 percent during the last decade. PDR rose in 2009 and 2010, but only to be back to balanced figures since 2011 due to the decreasing financial costs and higher growth rates. It is remarkable that the costs of German public debt are now lower than in the precrisis years, as investors are using its debt as a refuge. The main positive drivers have been growth and PDR, while the increasing levels of debt are mostly a result of the banking bailouts. We presume the large 


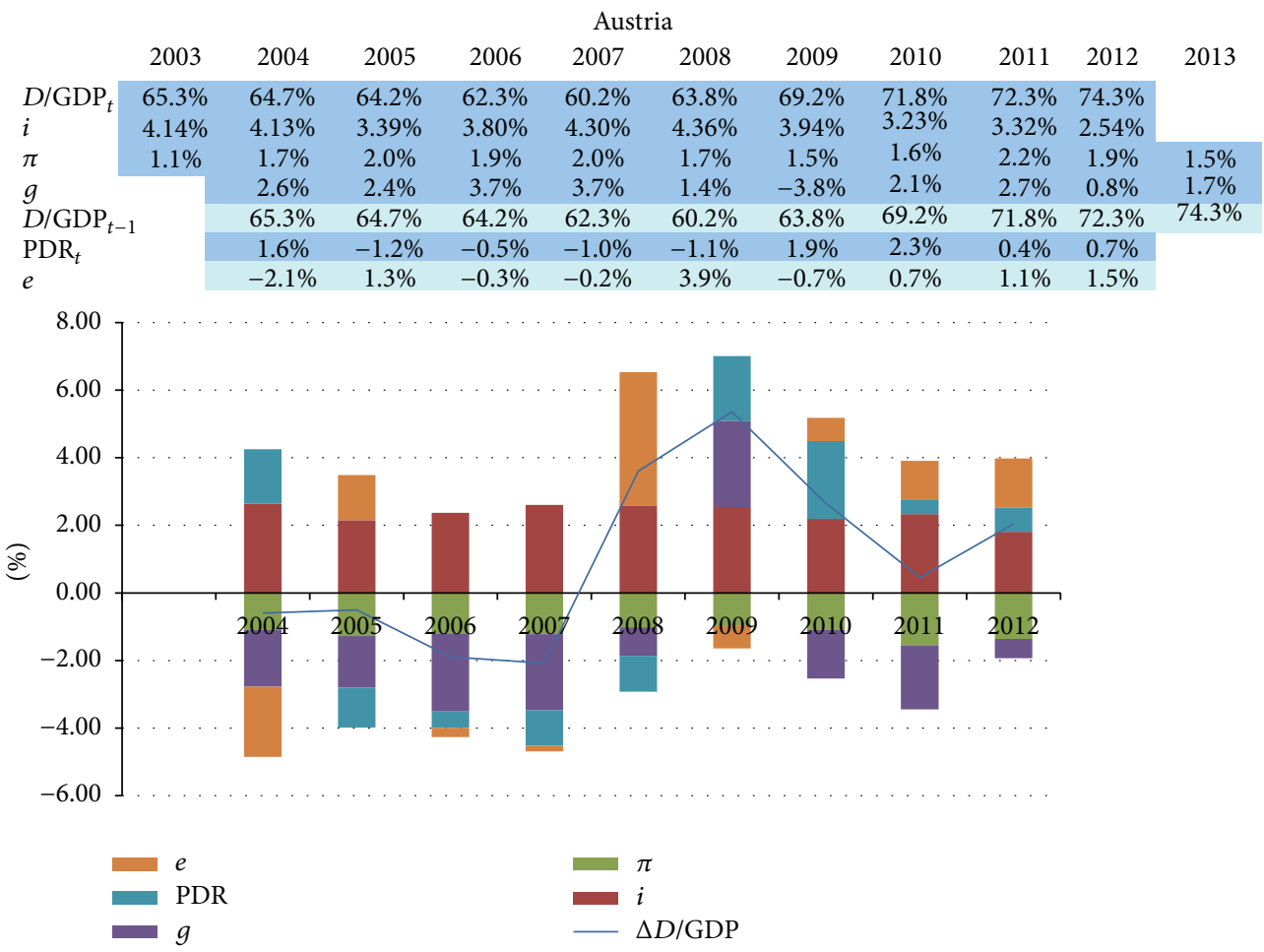

Figure 3: Decomposition of debt dynamics for Austria.

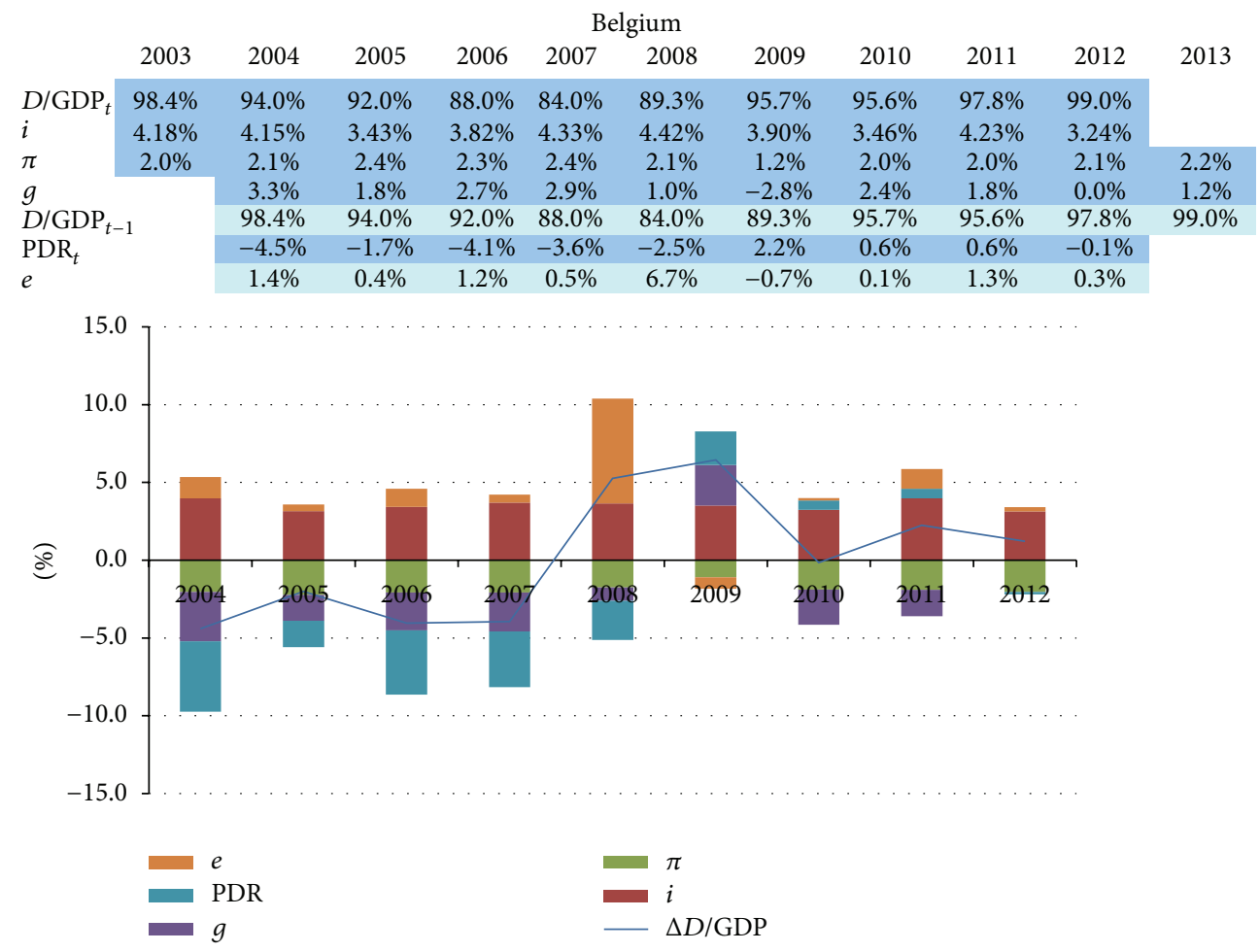

Figure 4: Decomposition of debt dynamics for Belgium. 


\begin{tabular}{lccccccccccc} 
& & \multicolumn{1}{c}{ Finland } \\
& 2003 & 2004 & 2005 & 2006 & 2007 & 2008 & 2009 & 2010 & 2011 & 2012 & 2013 \\
$\mathrm{D} / \mathrm{GDP}_{t}$ & $44.5 \%$ & $44.4 \%$ & $41.7 \%$ & $39.6 \%$ & $35.2 \%$ & $33.9 \%$ & $43.5 \%$ & $48.6 \%$ & $49.1 \%$ & $52.6 \%$ & \\
$i$ & $4.13 \%$ & $4.11 \%$ & $3.35 \%$ & $3.78 \%$ & $4.29 \%$ & $4.29 \%$ & $3.74 \%$ & $3.01 \%$ & $3.01 \%$ & $1.95 \%$ & \\
$\pi$ & $-0.7 \%$ & $0.5 \%$ & $0.5 \%$ & $0.8 \%$ & $3.0 \%$ & $2.9 \%$ & $1.5 \%$ & $0.4 \%$ & $3.1 \%$ & $2.7 \%$ & $2.1 \%$ \\
$g$ & & $4.1 \%$ & $2.9 \%$ & $4.4 \%$ & $5.3 \%$ & $0.3 \%$ & $-8.5 \%$ & $3.3 \%$ & $2.7 \%$ & $0.8 \%$ & $1.6 \%$ \\
$\mathrm{D} / \mathrm{GDP}_{t-1}$ & $44.5 \%$ & $44.4 \%$ & $41.7 \%$ & $39.6 \%$ & $35.2 \%$ & $33.9 \%$ & $43.5 \%$ & $48.6 \%$ & $49.1 \%$ & $52.6 \%$ \\
$\mathrm{PDR}_{t}$ & & $-4.0 \%$ & $-4.3 \%$ & $-3.7 \%$ & $-4.7 \%$ & $-3.3 \%$ & $3.4 \%$ & $3.0 \%$ & $1.0 \%$ & $1.7 \%$ & \\
$e$ & & $4.1 \%$ & $1.7 \%$ & $2.2 \%$ & $1.7 \%$ & $1.7 \%$ & $2.3 \%$ & $2.4 \%$ & $0.8 \%$ & $2.5 \%$ &
\end{tabular}

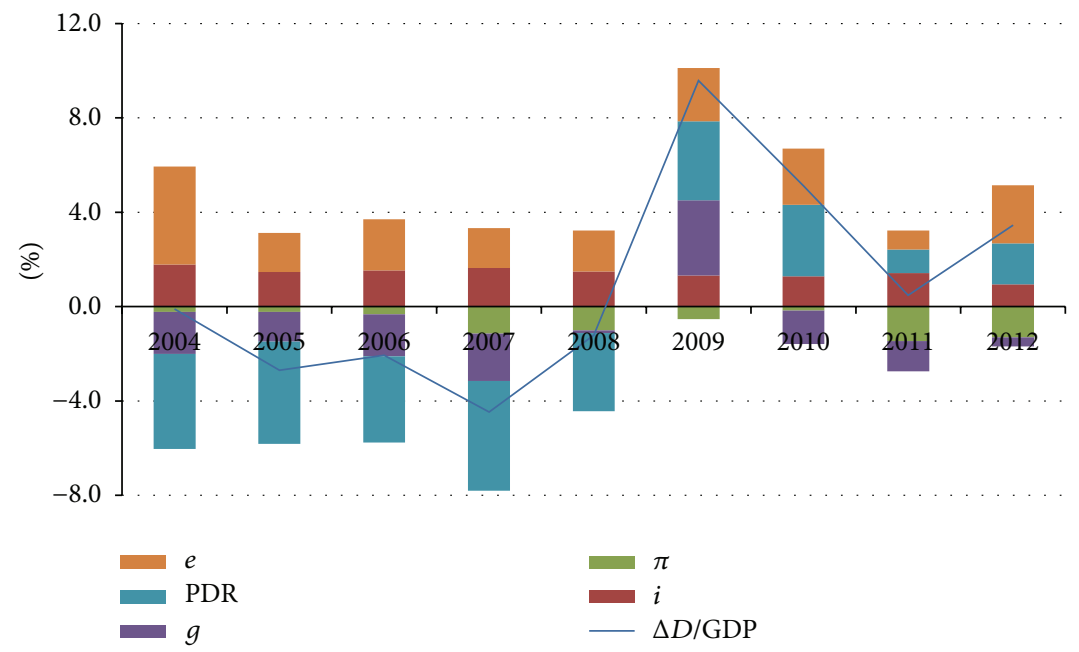

Figure 5: Decomposition of debt dynamics for Finland.

\begin{tabular}{lccccccccccc} 
& & \multicolumn{1}{c}{ France } \\
& 2003 & 2004 & 2005 & 2006 & 2007 & 2008 & 2009 & 2010 & 2011 & 2012 & 2013 \\
$/ \mathrm{GDP}_{t}$ & $63.2 \%$ & $65.0 \%$ & $66.7 \%$ & $64.1 \%$ & $64.2 \%$ & $68.2 \%$ & $79.2 \%$ & $82.3 \%$ & $86.0 \%$ & $90.0 \%$ & \\
$i$ & $4.13 \%$ & $4.10 \%$ & $3.41 \%$ & $3.80 \%$ & $4.30 \%$ & $4.23 \%$ & $3.65 \%$ & $3.12 \%$ & $3.32 \%$ & $2.68 \%$ & \\
$\pi$ & $2.0 \%$ & $1.7 \%$ & $1.9 \%$ & $2.1 \%$ & $2.6 \%$ & $2.5 \%$ & $0.7 \%$ & $1.1 \%$ & $1.3 \%$ & $1.5 \%$ & $1.8 \%$ \\
$g$ & & $2.5 \%$ & $1.8 \%$ & $2.5 \%$ & $2.3 \%$ & $-0.1 \%$ & $-3.1 \%$ & $1.7 \%$ & $1.7 \%$ & $0.5 \%$ & $1.3 \%$ \\
$\mathrm{D} / \mathrm{GDP}_{t-1}$ & & $63.2 \%$ & $65.0 \%$ & $66.7 \%$ & $64.1 \%$ & $64.2 \%$ & $68.2 \%$ & $79.2 \%$ & $82.3 \%$ & $86.0 \%$ & $90.0 \%$ \\
$\mathrm{PDR}_{t}$ & & $0.8 \%$ & $0.3 \%$ & $0.0 \%$ & $0.3 \%$ & $0.7 \%$ & $5.4 \%$ & $4.8 \%$ & $2.7 \%$ & $2.2 \%$ & \\
$e$ & $1.0 \%$ & $1.6 \%$ & $-2.1 \%$ & $0.3 \%$ & $2.2 \%$ & $1.4 \%$ & $-1.9 \%$ & $0.8 \%$ & $1.2 \%$ &
\end{tabular}

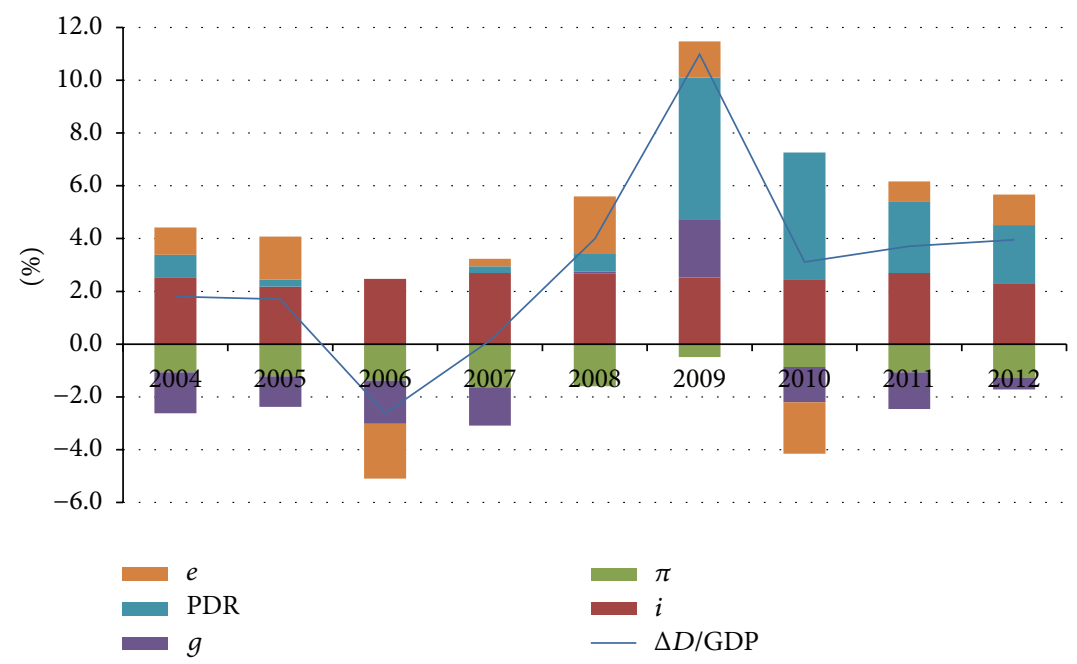

FIgURE 6: Decomposition of debt dynamics for France. 


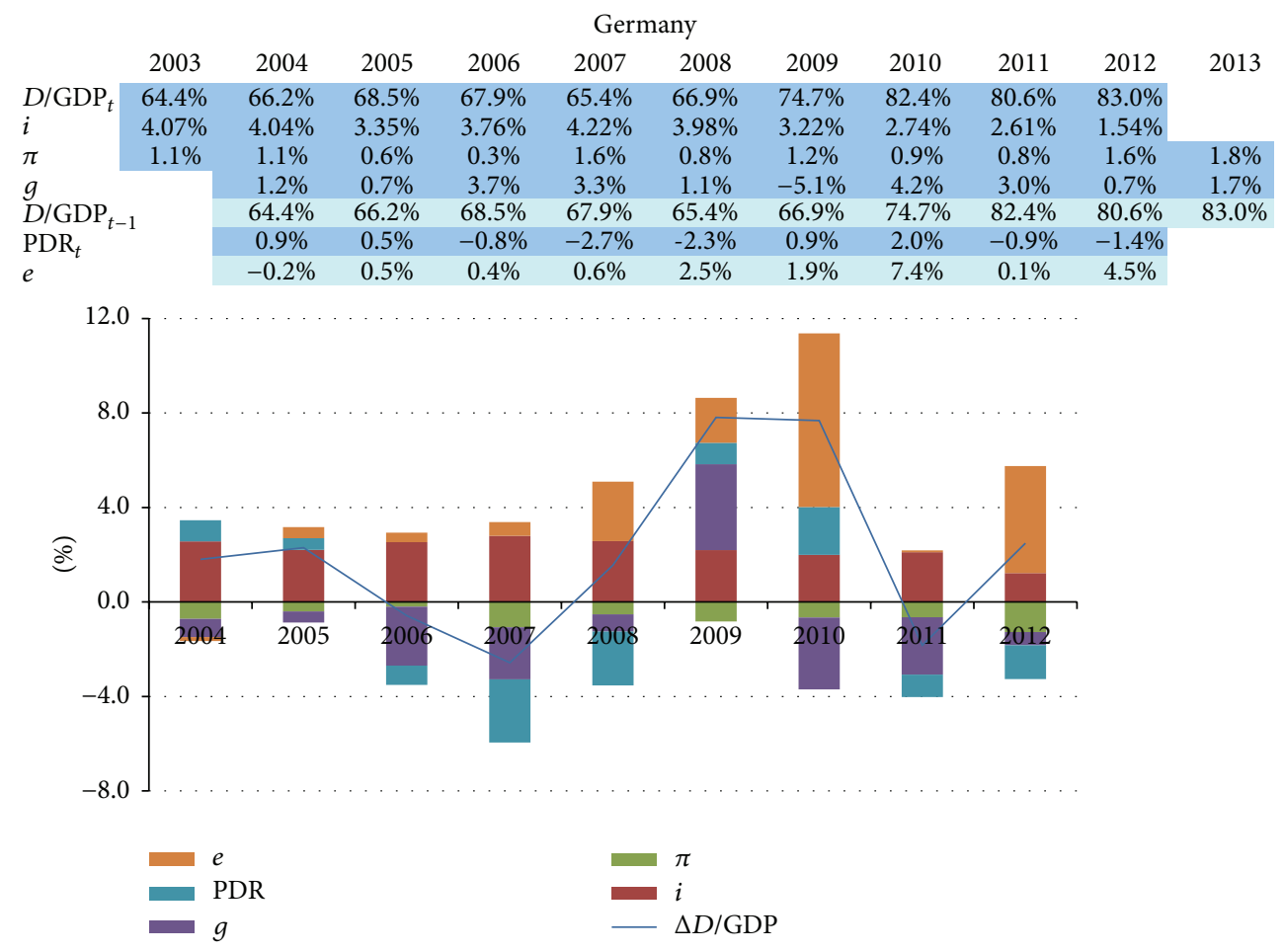

FIGURE 7: Decomposition of debt dynamics for Germany.

value of the residual in 2012 is mostly an effect of using market rates as a proxy for cost of debt, since the lower interest rates Germany is paying today only apply to new debt.

Greece. It has suffered increasing levels of debt before the financial crisis, only to experience a debt explosion since then. The main drivers of debt dynamics before the crisis were the cost of debt and, to a lower extent, the primary deficit. After 2008 financial costs soared, which together with negative growth rates and the unbalanced PDR lead to an increase of $60 \%$ in the debt-to-GDP ratio. Austerity measures and the external bailouts helped to correct PDR and financial costs but only at the cost of sinking growth. The more stable levels of debt in year 2012 are therefore better explained as a consequence of the debt-restructuring episode in 2012 of $53.5 \%$ over 206 billion eur of Greek debt [26], which carried the debt ratio from a forecast of about $200 \%$ in 2012 to roughly $170 \%$. The lower interest payments in next years plus fiscal consolidation and a privatization program are expected to drive debt at $120 \%$ of GDP by 2020 .

Ireland. The explosion of the housing bubble and the collapse of the Irish financial system that followed made debt-toGDP ratios dramatically increase. The effects of the banking bailout were noticeable between 2008 and 2011, with a strong deterioration of fiscal balance, particularly in year 2010. On that year it also took place the $€ 85$ billion sovereign bailout. After that, an appreciable correction began, with fiscal balance and macroeconomic data (both growth and avoiding deflation) improving since then. However, debt ratios have not shown signs of stabilization yet.
Italy. This country shows two particularities with respect to others in the sample. First, the high debt ratios carried already early in the period. Second, the healthy fiscal balance it shows, with positive PSR all over the period (with the small exceptions of 2009 and 2010). Given this, the main driver of Italian debt dynamics has been the cost of debt, which is showing to be a heavy burden on the backs of the Italians. Only inflation has provided a positive effect, while low growth is dragging the performance-with recession striking again in 2012.

The Netherlands. Dutch public finances showed enviable health until the crisis hit the EU in 2008. In that year debtto-GDP increased $13.2 \%$, while 2009 put an end to positive PSRs. The disastrous effects over public finances in 2008largely due to the nationalization ABN Amro and Fortis Bank Nederland to create ABN AMRO Group N.V.- - are clearly visible in the residual error that year. Since then, the main driver of debt dynamics has been PDR.

Portugal. In the precrisis years debt was already increasing (with the exception of 2006). The crisis worsened this performance, fueled by a deterioration of primary deficits and a soaring cost of debt in secondary markets that lead Portugal to ask for a $€ 78$ billion eur bailout in 2011. Portugal is being the "model student" that meets all the requirements by the Troika, particularly materialized on a spectacular adjustment of PDRs in 2011 helped it by a one-off $€ 6$ billion transfer (about $4 \%$ of GDP) of pension funds. However, debt ratios are still out of control, with depression $(-3.3 \%$ growth rate in $2012_{\mathrm{f}}$ ) being the main driver. 


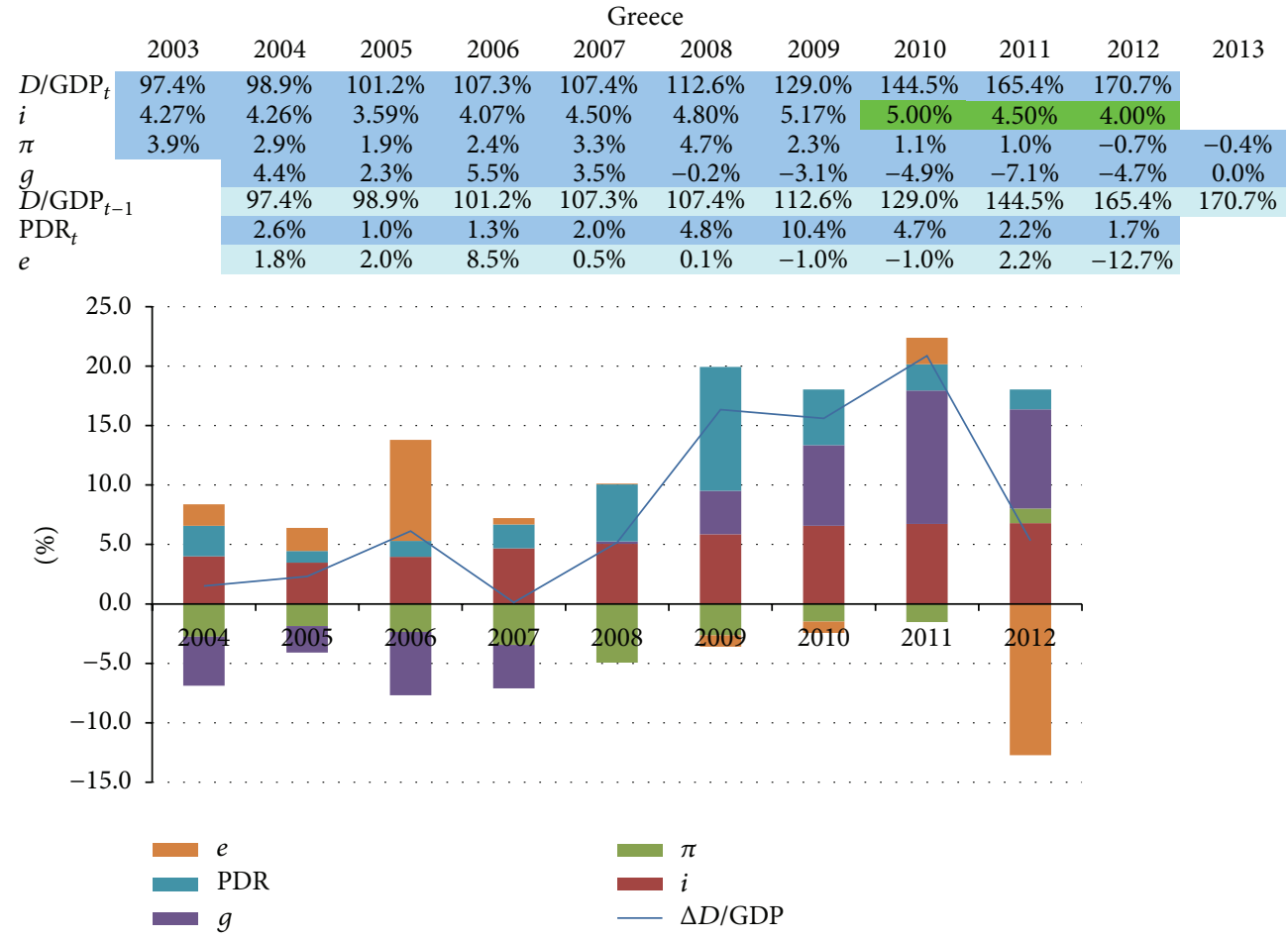

FIGURE 8: Decomposition of debt dynamics for Greece.

Spain. Like Ireland, Spain suffered the explosion of a housing bubble by 2008. The first effects over the debt-to-GDP ratios were driven by the deterioration of public finances due to the drop in public revenues and the sharp increase in the unemployment rate. However, the largest effect over debt levels came with the bank bailout provided by the European authorities later on in 2012. The debt ratio forecasted by the IMF for Spain in 2012 includes a full use of the $€ 100$ billion (10\% GDP, aprox.) of the banking bailout. However, more recent information provided by the Spanish government suggests the volume of funds employed to capitalize the nationalized banks will be below $€ 50$ billion. Therefore, the increase in the debt ratio by 2012 might be lower than the $20 \%$ we used here. In the precrisis years, public finances were healthy and historic budget surpluses (due in part by higher revenues from the housing bubble) were the main driver of a decreasing debt ratio. After the crisis, PDR has largely been the main driver of a deteriorating debt dynamics.

4.2. GIPSI versus EU Core Countries. We compare now the performance as a group of EU core versus GIPSI countries. Table 2 summarizes data for the eleven countries during the whole period of analysis (2004-2012 $)$. Change in debt-toGDP measures the total increase in the debt ratio during the period, while data for GDP growth, inflation, and primary balance (expressed as PSR) are average figures during the same period. We focus here on these three factors as the cost of debt and residuals are beyond the scope of the economic policies these countries may implement. We also provide average figures for the four variables in each group.
We may see the main differences between debtor and creditor countries. First, core countries experimented more stable levels of debt, while for GIPSIs the $56.87 \%$ average debt increase should be taken carefully, as the range goes from the $22.4 \%$ of Italy to the $87.0 \%$ of Ireland. Second, the main drivers of the better performance by EU core are the primary balance and-to a lower extent-growth. However, the higher average deficit of GIPSI countries encompasses large variationscompare again the values for Italy and Ireland. Third, average inflation was similar to both groups, though variance was again significantly higher for GIPSI countries. However, the analysis for the entire period does not take into account the acute changes that both groups of countries experienced before and after the triggering of the crisis. It is therefore more illustrative to split the sample into two periods, P1 (20042007) and P2 (2008-2012 $)$ ). This analysis is illustrated in Table 3.

Now the asymmetric effects caused by the sovereign and financial crises are more clearly stated. The most significant result refers to the different evolution of the debt-to-GDP rate. On one hand, both groups were able to reduce debt in $\mathrm{P} 1$, with the deterioration of debt dynamics coming in P2. On the other, it was in P2 where all the relative misbehavior of GIPSI countries became clear. Indeed, in P1 the debt-toGDP average for Ireland, Italy, and Spain is similar to that of the EU core countries, and average PSR is even better. If we focus on period P2 we notice all three factors, inflation included, were driving factors of the bad performance, with the strong deterioration of fiscal balances of GIPSI countries $(-5.16 \%)$ being the most significant. Data for Italy, Spain, and Ireland is denoted Average 3 in Table 3, excluding Greece and 


\begin{tabular}{|c|c|c|c|c|c|c|c|c|c|c|c|}
\hline \multicolumn{12}{|c|}{ Ireland } \\
\hline & 2003 & 2004 & 2005 & 2006 & 2007 & 2008 & 2009 & 2010 & 2011 & 2012 & 2013 \\
\hline$D / \mathrm{GDP}_{t}$ & $30.7 \%$ & $29.5 \%$ & $27.3 \%$ & $24.8 \%$ & $25.0 \%$ & $44.5 \%$ & $64.9 \%$ & $92.2 \%$ & $106.5 \%$ & $117.7 \%$ & \\
\hline 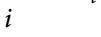 & $4.13 \%$ & $4.08 \%$ & $3.33 \%$ & $3.77 \%$ & $4.31 \%$ & $4.53 \%$ & $5.23 \%$ & $5.74 \%$ & $4.50 \%$ & $4.00 \%$ & \\
\hline$\pi$ & $3.6 \%$ & $2.2 \%$ & $2.5 \%$ & $3.4 \%$ & $0.7 \%$ & $-3.2 \%$ & $-4.6 \%$ & $-2.2 \%$ & $0.2 \%$ & $1.2 \%$ & $1.2 \%$ \\
\hline$g$ & & $4.4 \%$ & $5.9 \%$ & $5.4 \%$ & $5.4 \%$ & $-2.1 \%$ & $-5.5 \%$ & $-0.8 \%$ & $1.4 \%$ & $0.5 \%$ & $1.9 \%$ \\
\hline $\mathrm{D} / \mathrm{GDP}$ & & $30.7 \%$ & $29.5 \%$ & $27.3 \%$ & $24.8 \%$ & $25.0 \%$ & $44.5 \%$ & $64.9 \%$ & $92.2 \%$ & $106.5 \%$ & $117.7 \%$ \\
\hline $\mathrm{PDR}_{t}$ & & $-2.5 \%$ & $-2.7 \%$ & $-3.9 \%$ & $-1.0 \%$ & $6.2 \%$ & $12.1 \%$ & $27.9 \%$ & $9.6 \%$ & $4.4 \%$ & \\
\hline & & $2.1 \%$ & $1.9 \%$ & $2.7 \%$ & $1.6 \%$ & $10.7 \%$ & $0.8 \%$ & $-6.4 \%$ & $2.0 \%$ & $4.5 \%$ & \\
\hline
\end{tabular}

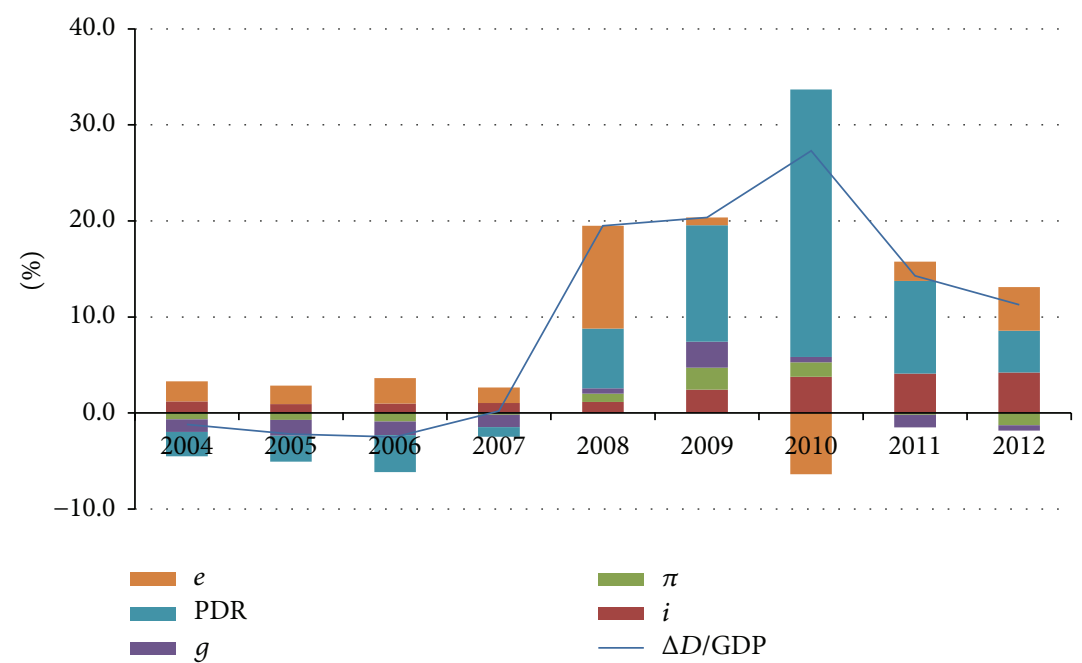

FIGURE 9: Decomposition of debt dynamics for Ireland.

\begin{tabular}{lccccccccccc} 
& & \multicolumn{1}{c}{ Italy } & & & & & \\
& 2003 & 2004 & 2005 & 2006 & 2007 & 2008 & 2009 & 2010 & 2011 & 2012 & 2013 \\
$/ \mathrm{GDP}_{t}$ & $103.9 \%$ & $103.4 \%$ & $105.7 \%$ & $106.1 \%$ & $103.1 \%$ & $105.7 \%$ & $116.0 \%$ & $118.6 \%$ & $120.1 \%$ & $126.3 \%$ & \\
$i$ & $4.25 \%$ & $4.26 \%$ & $3.56 \%$ & $4.05 \%$ & $4.49 \%$ & $4.68 \%$ & $4.31 \%$ & $4.04 \%$ & $5.42 \%$ & $5.73 \%$ & \\
$\pi$ & $3.1 \%$ & $2.4 \%$ & $1.8 \%$ & $1.7 \%$ & $2.4 \%$ & $2.5 \%$ & $2.1 \%$ & $0.4 \%$ & $1.3 \%$ & $2.1 \%$ & $2.2 \%$ \\
$g$ & & $1.7 \%$ & $0.9 \%$ & $2.2 \%$ & $1.7 \%$ & $-1.2 \%$ & $-5.5 \%$ & $1.8 \%$ & $0.4 \%$ & $-1.4 \%$ & $0.4 \%$ \\
$D_{/ G D P}$ & & $103.9 \%$ & $103.4 \%$ & $105.7 \%$ & $106.1 \%$ & $103.1 \%$ & $105.7 \%$ & $116.0 \%$ & $118.6 \%$ & $120.1 \%$ & $126.3 \%$ \\
$\mathrm{PDR}_{t}$ & $-1.2 \%$ & $-0.2 \%$ & $-1.0 \%$ & $-3.1 \%$ & $-2.2 \%$ & $1.0 \%$ & $0.3 \%$ & $-0.8 \%$ & $-2.6 \%$ & \\
$e$ & & $0.6 \%$ & $1.6 \%$ & $1.3 \%$ & $-0.2 \%$ & $1.4 \%$ & $0.7 \%$ & $0.3 \%$ & $-2.1 \%$ & $2.8 \%$ &
\end{tabular}

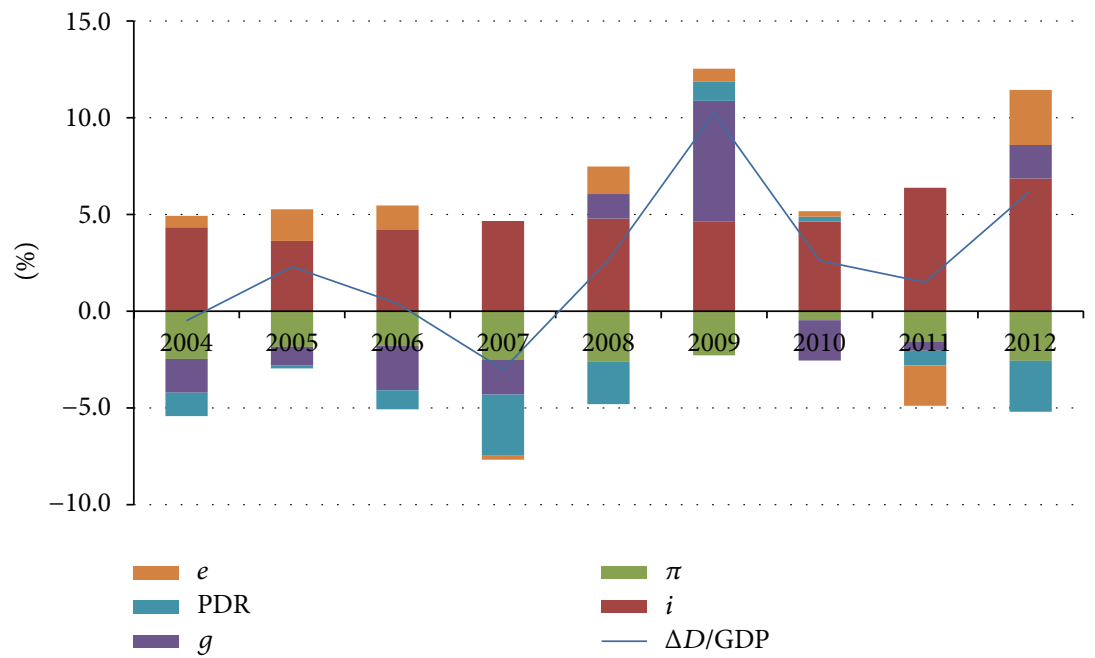

FIgURE 10: Decomposition of debt dynamics for Italy. 


\begin{tabular}{|c|c|c|c|c|c|c|c|c|c|c|c|}
\hline \multicolumn{12}{|c|}{ Netherlands } \\
\hline & 2003 & 2004 & 2005 & 2006 & 2007 & 2008 & 2009 & 2010 & 2011 & 2012 & 2013 \\
\hline$D / \mathrm{GDP}_{t}$ & $52.0 \%$ & $52.4 \%$ & $51.8 \%$ & $47.4 \%$ & $45.3 \%$ & $58.5 \%$ & $60.8 \%$ & $62.9 \%$ & $65.2 \%$ & $68.2 \%$ & \\
\hline$i$ & $4.12 \%$ & $4.10 \%$ & $3.37 \%$ & $3.78 \%$ & $4.29 \%$ & $4.23 \%$ & $3.69 \%$ & $2.99 \%$ & $2.99 \%$ & $2.02 \%$ & \\
\hline$\pi$ & $2.2 \%$ & $0.7 \%$ & $2.4 \%$ & $1.8 \%$ & $1.8 \%$ & $2.1 \%$ & $0.1 \%$ & $1.1 \%$ & $1.2 \%$ & $1.6 \%$ & $1.7 \%$ \\
\hline$g$ & & $2.2 \%$ & $2.0 \%$ & $3.4 \%$ & $3.9 \%$ & $1.8 \%$ & $-3.7 \%$ & $1.6 \%$ & $1.0 \%$ & $-0.9 \%$ & $0.7 \%$ \\
\hline $\mathrm{D} / \mathrm{GDP}_{t}$ & & $52.0 \%$ & $52.4 \%$ & $51.8 \%$ & $47.4 \%$ & $45.3 \%$ & $58.5 \%$ & $60.8 \%$ & $62.9 \%$ & $65.2 \%$ & $68.2 \%$ \\
\hline $\mathrm{PDR}_{t}$ & & $-0.7 \%$ & $-2.1 \%$ & $-2.1 \%$ & $-1.8 \%$ & $-2.1 \%$ & $3.8 \%$ & $3.7 \%$ & $3.1 \%$ & $2.4 \%$ & \\
\hline$e^{-t}$ & & $0.5 \%$ & $2.0 \%$ & $-1.6 \%$ & $0.4 \%$ & $15.1 \%$ & $-5.9 \%$ & $-1.7 \%$ & $-1.3 \%$ & $-0.2 \%$ & \\
\hline
\end{tabular}

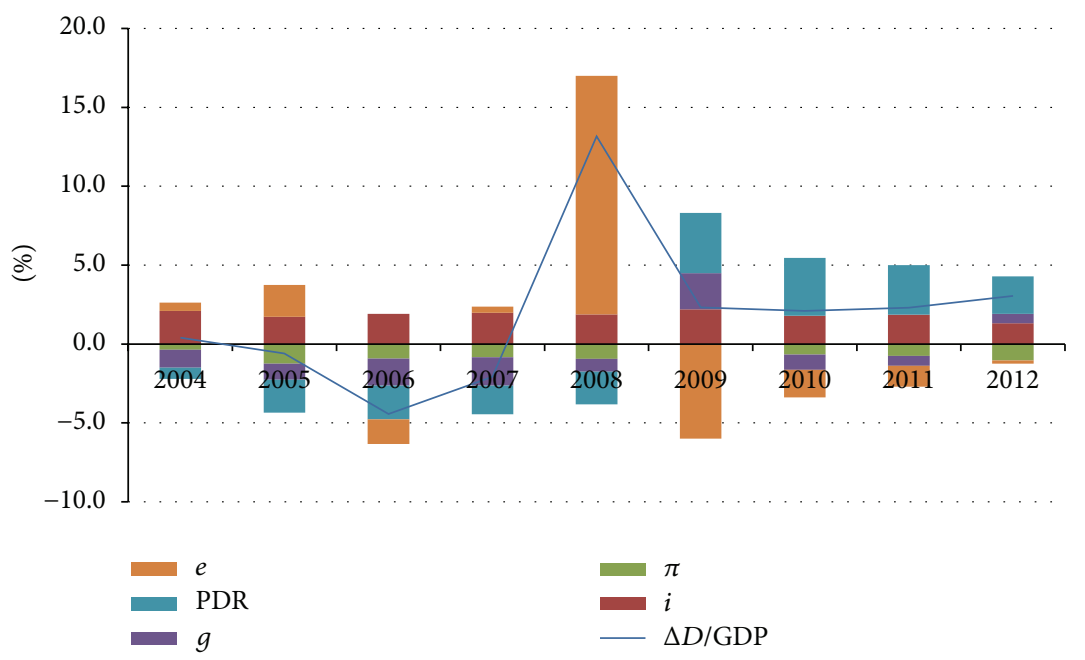

Figure 11: Decomposition of debt dynamics for The Netherlands.

\begin{tabular}{|c|c|c|c|c|c|c|c|c|c|c|c|}
\hline \multicolumn{12}{|c|}{ Portugal } \\
\hline & 2003 & 2004 & 2005 & 2006 & 2007 & 2008 & 2009 & 2010 & 2011 & 2012 & \multirow[t]{2}{*}{2013} \\
\hline$D / \mathrm{GDP}_{t}$ & $59.4 \%$ & $61.9 \%$ & $67.7 \%$ & $63.7 \%$ & $68.3 \%$ & $71.6 \%$ & $83.1 \%$ & $93.3 \%$ & $107.8 \%$ & $119.1 \%$ & \\
\hline r. & $4.18 \%$ & $4.14 \%$ & $3.44 \%$ & $3.92 \%$ & $4.43 \%$ & $4.52 \%$ & $4.21 \%$ & $5.40 \%$ & $7.00 \%$ & $4.00 \%$ & \\
\hline$\pi$ & $3.0 \%$ & $2.5 \%$ & $2.5 \%$ & $2.8 \%$ & $2.8 \%$ & $1.6 \%$ & $0.9 \%$ & $1.1 \%$ & $0.7 \%$ & $0.7 \%$ & $1.3 \%$ \\
\hline \multirow{2}{*}{\multicolumn{2}{|c|}{${ }_{D} / \mathrm{GDP}_{t-1}$}} & $1.6 \%$ & $0.8 \%$ & $1.4 \%$ & $2.4 \%$ & $0.0 \%$ & $-2.9 \%$ & $1.4 \%$ & $-1.7 \%$ & $-3.3 \%$ & $0.3 \%$ \\
\hline & & $59.4 \%$ & $61.9 \%$ & $67.7 \%$ & $63.7 \%$ & $68.3 \%$ & $71.6 \%$ & $83.1 \%$ & $93.3 \%$ & $107.8 \%$ & $119.1 \%$ \\
\hline \multirow{2}{*}{\multicolumn{2}{|c|}{$\begin{array}{l}\mathrm{PDR}_{t} \\
e\end{array}$}} & $1.4 \%$ & $4.0 \%$ & $1.3 \%$ & $0.6 \%$ & $1.0 \%$ & $7.5 \%$ & $7.1 \%$ & $0.6 \%$ & $0.7 \%$ & \\
\hline & & $1.1 \%$ & $1.8 \%$ & $-5.1 \%$ & $4.5 \%$ & $0.3 \%$ & $-0.6 \%$ & $0.9 \%$ & $6.3 \%$ & $3.2 \%$ & \\
\hline
\end{tabular}

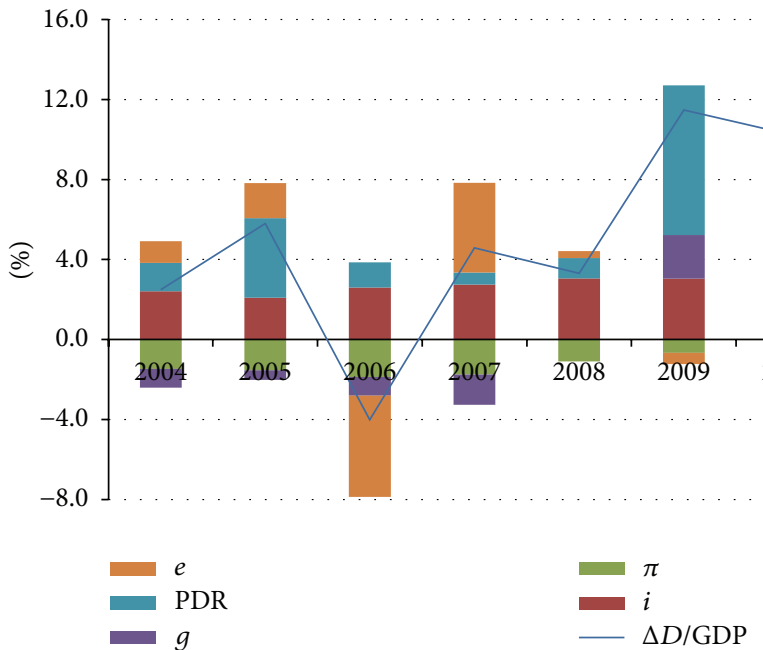

FIgure 12: Decomposition of debt dynamics for Portugal. 


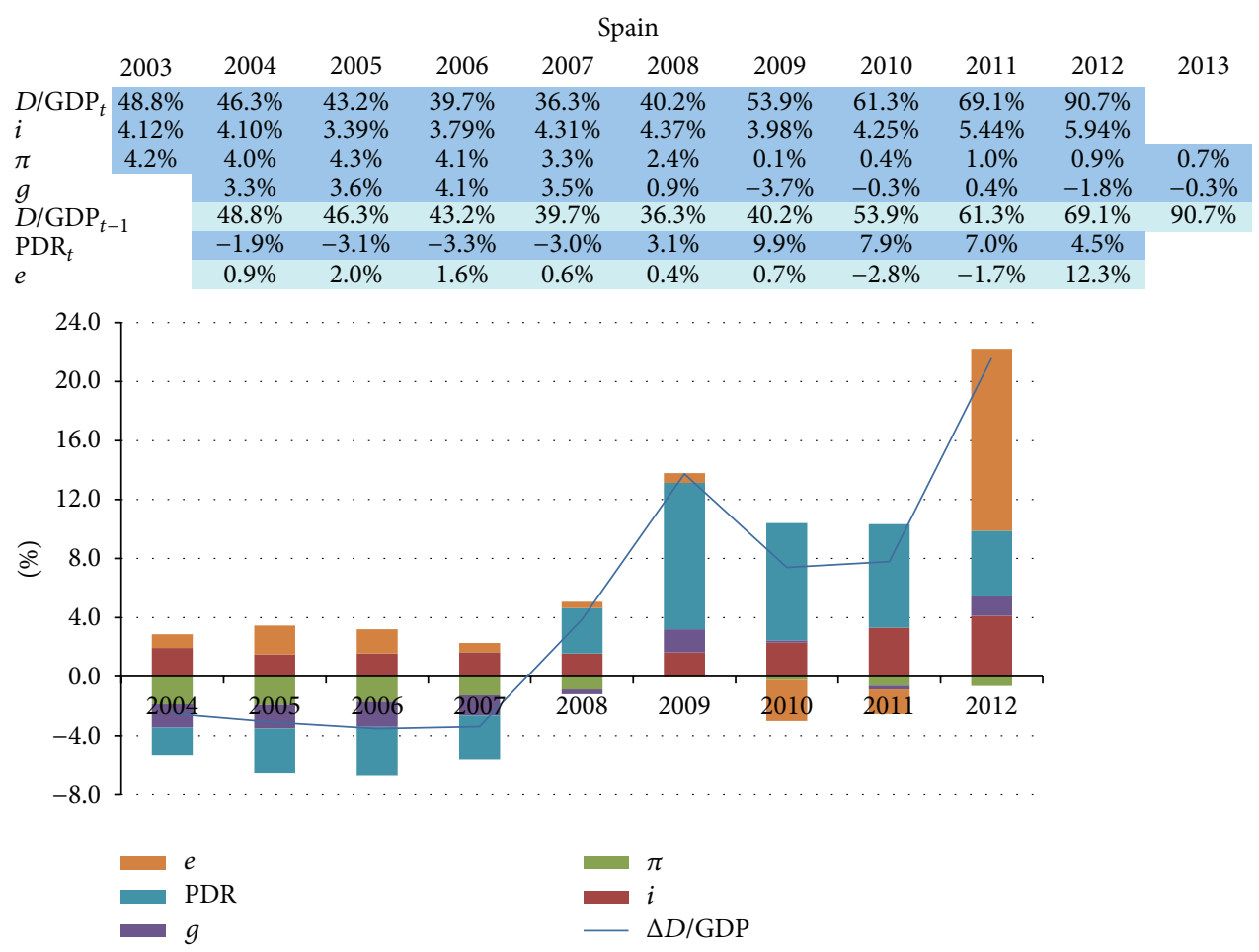

FIGURE 13: Decomposition of debt dynamics for Spain.

TABLE 2: Episodes of debt, EU core versus GIPSI countries, entire period 2004-2012 $\mathrm{f}$. Differentiating episodes by the change in the debt-toGDP ratio.

\section{TOTAL}

Episodes

\begin{tabular}{|c|c|c|c|c|}
\hline Country & $\begin{array}{l}\text { Change in debt to } \\
\text { GDP (percent) }\end{array}$ & GDP growth (percent) & Inflation (percent) & $\begin{array}{c}\text { Primary balance } \\
(\% \text { of GDP })\end{array}$ \\
\hline Austria & 9.04 & 1.73 & 1.83 & -0.36 \\
\hline Belgium & 0.63 & 1.46 & 2.07 & 1.47 \\
\hline Finland & 8.08 & 1.70 & 1.71 & 1.21 \\
\hline France & 26.77 & 1.09 & 1.71 & -1.91 \\
\hline Germany & 18.64 & 1.42 & 0.99 & 0.43 \\
\hline The Netherlands & 16.20 & 1.26 & 1.42 & -0.47 \\
\hline Average & 13.23 & 1.44 & 1.62 & 0.06 \\
\hline \multicolumn{5}{|c|}{ Episodes } \\
\hline Country & $\begin{array}{l}\text { Change in debt } \\
\text { to GDP (percent) }\end{array}$ & GDP growth (percent) & Inflation (percent) & $\begin{array}{c}\text { Primary balance } \\
(\% \text { of GDP })\end{array}$ \\
\hline Greece & 73.33 & -0.48 & 2.10 & -3.40 \\
\hline Ireland & 87.04 & 1.62 & 0.02 & -5.56 \\
\hline Italy & 22.43 & 0.07 & 1.86 & 1.10 \\
\hline Portugal & 59.67 & -0.03 & 1.73 & -2.68 \\
\hline Spain & 41.89 & 1.11 & 2.28 & -2.35 \\
\hline Average & 56.87 & 0.46 & 1.60 & -2.58 \\
\hline
\end{tabular}

Source: own elaboration, data from IMF [9], Eurostat, and ECB SDW. 
TABLE 3: Episodes of debt, analysis of periods P1 (2004-2007) and P2 (2008-2012 $)$.

(a) Differentiating episodes by the change in the debt-to-GDP ratio

\begin{tabular}{|c|c|c|c|c|}
\hline \multicolumn{5}{|c|}{ P1 } \\
\hline \multicolumn{5}{|c|}{ Episodes } \\
\hline Country & $\begin{array}{l}\text { Change in debt to } \\
\text { GDP (percent) }\end{array}$ & GDP growth (percent) & Inflation (percent) & $\begin{array}{c}\text { Primary balance } \\
(\% \text { of GDP })\end{array}$ \\
\hline Austria & -5.08 & 3.10 & 1.90 & 0.28 \\
\hline Belgium & -14.39 & 2.68 & 2.30 & 3.48 \\
\hline Finland & -9.34 & 4.18 & 1.20 & 4.17 \\
\hline France & 1.01 & 2.28 & 2.08 & -0.34 \\
\hline Germany & 0.96 & 2.23 & 0.90 & 0.53 \\
\hline The Netherlands & -6.71 & 2.88 & 1.68 & 1.69 \\
\hline Average & -5.59 & 2.89 & 1.68 & 1.63 \\
\hline \multicolumn{5}{|c|}{ Episodes } \\
\hline Country & $\begin{array}{l}\text { Change in debt to } \\
\text { GDP (percent) }\end{array}$ & GDP growth (percent) & Inflation (percent) & $\begin{array}{c}\text { Primary balance } \\
(\% \text { of GDP })\end{array}$ \\
\hline Greece & 10.05 & 3.93 & 2.63 & -1.72 \\
\hline Ireland & -5.71 & 5.28 & 2.20 & 2.53 \\
\hline Italy & -0.82 & 1.63 & 2.08 & 1.37 \\
\hline Portugal & 8.87 & 1.55 & 2.65 & -1.81 \\
\hline Spain & -12.50 & 3.63 & 3.93 & 2.83 \\
\hline Average & -0.02 & 3.20 & 2.70 & 0.64 \\
\hline Average3 & -6.34 & 3.51 & 2.73 & 2.24 \\
\hline
\end{tabular}

(b) Differentiating episodes by the change in the debt-to-GDP ratio

P2

Episodes

\begin{tabular}{|c|c|c|c|c|}
\hline Country & $\begin{array}{l}\text { Change in debt to } \\
\text { GDP (percent) }\end{array}$ & GDP growth (percent) & Inflation (percent) & $\begin{array}{c}\text { Primary balance } \\
\text { (\% of GDP) }\end{array}$ \\
\hline Austria & 14.11 & 0.64 & 1.78 & -0.86 \\
\hline Belgium & 15.03 & 0.48 & 1.88 & -0.14 \\
\hline Finland & 17.42 & -0.28 & 2.12 & -1.16 \\
\hline France & 25.75 & 0.14 & 1.42 & -3.16 \\
\hline Germany & 17.68 & 0.78 & 1.06 & 0.35 \\
\hline The Netherlands & 22.91 & -0.04 & 1.22 & -2.19 \\
\hline Average & 18.82 & 0.29 & 1.58 & -1.19 \\
\hline \multicolumn{5}{|c|}{ Episodes } \\
\hline Country & $\begin{array}{l}\text { Change in debt to } \\
\text { GDP (percent) }\end{array}$ & GDP growth (percent) & Inflation (percent) & $\begin{array}{c}\text { Primary balance } \\
(\% \text { of GDP })\end{array}$ \\
\hline Greece & 63.28 & -4.00 & 1.68 & -4.75 \\
\hline Ireland & 92.76 & -1.30 & -1.72 & -12.04 \\
\hline Italy & 23.25 & -1.18 & 1.68 & 0.88 \\
\hline Portugal & 50.80 & -1.30 & 1.00 & -3.37 \\
\hline Spain & 54.39 & -0.90 & 0.96 & -6.49 \\
\hline Average & 56.90 & -1.74 & 0.72 & -5.16 \\
\hline
\end{tabular}

Source: own elaboration, data from IMF [9], Eurostat, and ECB SDW.

Portugal due to their worst performance compared with the other three GIPSI countries.

Similar results are observable when we analyze the decomposition of debt dynamics for both groups of countries.
Figures 14 and 15 compare the average impact of all factors on the evolution of debt-to-GDP ratios in periods P1 and P2.

In Figure 14 we may observe the deterioration of PDR figures, which is largely more pronounced for GIPSI countries. 


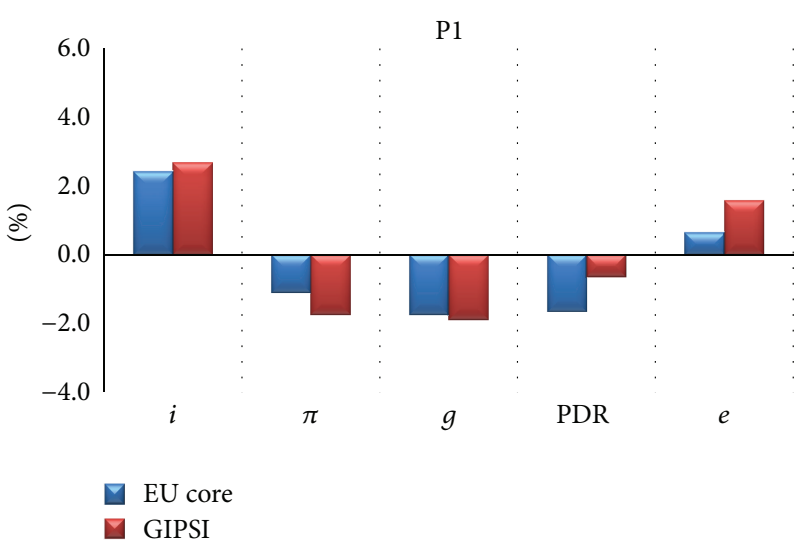

(a)

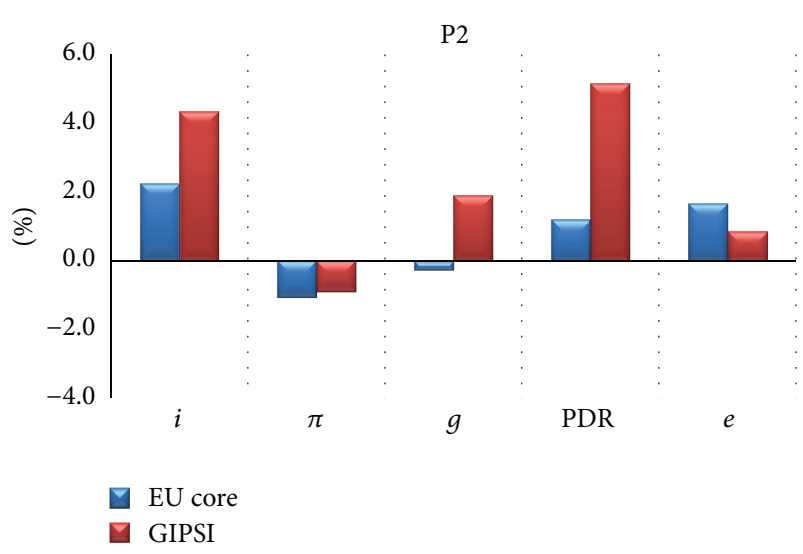

(b)

FIGURE 14: Debt dynamics, EU core versus GIPSI countries, periods P1 and P2. Source: own elaboration.

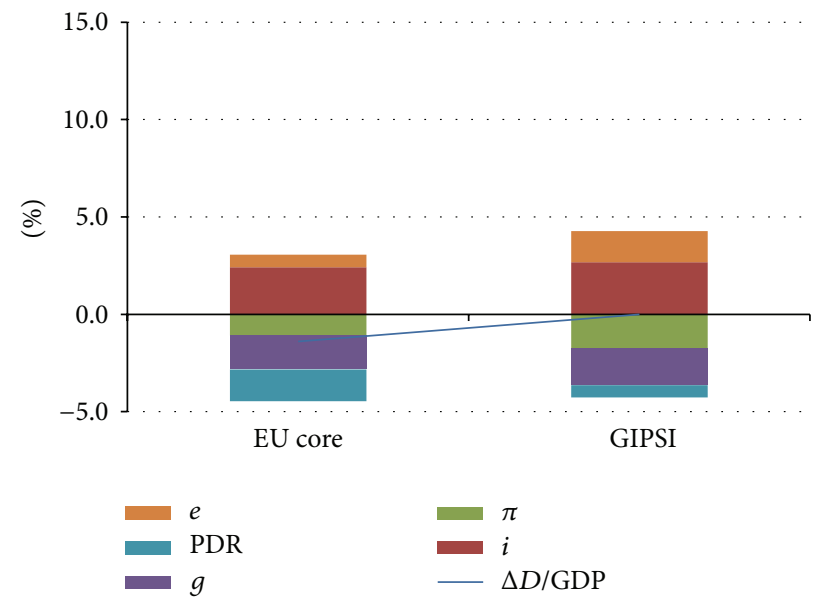

(a)

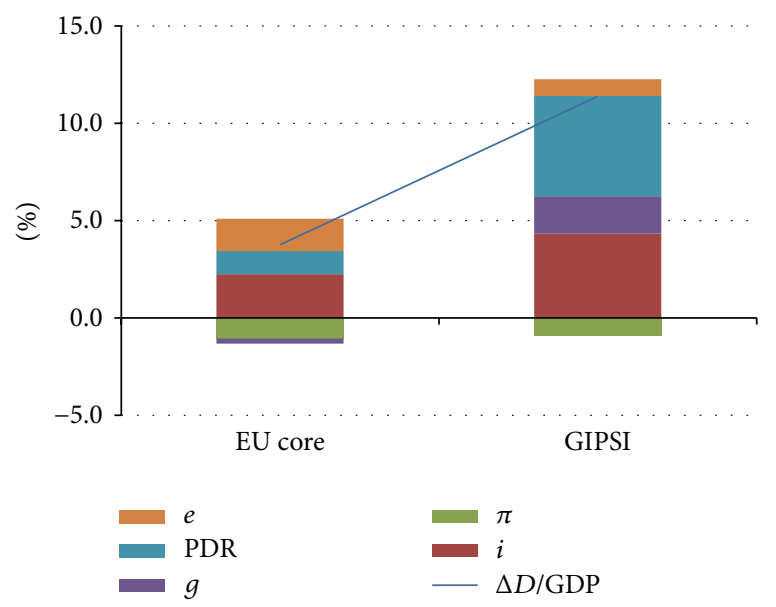

(b)

Figure 15: Debt dynamics, periods P1 (a) and P2 (b). Source: own elaboration.

Growth and cost of debt have also deteriorated, particularly for peripheral countries, while inflation was the only factor that helped to reduce debt in period P2. Figure 15 offers a similar interpretation, but with a clear picture of the accumulated effect over GIPSIs debt ratios in period P2.

Since period P2 better explains the bad performance of GIPSI countries, we focus our analysis there. Figure 16 summarizes the decomposition of debt dynamics in period P2 for each of the eleven countries. For most GIPSIs (but Italy) the main driver of the bad debt dynamics was the large deterioration of fiscal balances. Beyond that, the higher cost of debt and negative growth were also responsible. The only factor that helped GIPSIs was inflation.

We may alternatively represent some dispersion diagrams to make a pairwise comparison of the driving factors. These are the most relevant results for period P2. First, Figure 17 evidences a strong correlation between primary balance (PSR) and change in debt. One percentage point of additional fiscal imbalance has explained, on average for the eleven countries, from 2008 to 2012, an increase of $0.93 \%$ in the debt ratio every year $\left(R^{2}=86.4 \%\right.$, with $R^{2}=93.0 \%$ for GIPSIs $)$. Since GIPSI countries have experienced a large deterioration in their fiscal balances that is yet to be solved, a clear result of this analysis is that the main objective of any policy strategy for peripheral countries should be fiscal consolidation.

However, this strategy should not damage growth. Figure 18 evidences that there is also a positive (though weak, $\left.R^{2}=0.46\right)$ correlation between debt dynamics and growth.

This effect is even more intense: over five years, a percentage point of lower GDP growth caused, on average for the eleven countries, an increase of $1.94 \%$ in the debt ratio every year. Put it other words, whenever a fiscal consolidation of one percentage point reduces growth in more than half a point, the net effect would be an increased debt ratio. (However, we should be careful about this interpretation, both because the growth-debt ratio correlation is weak and because the statistical results for period P2 are not robust for period P1.) The classic fiscal consolidation versus growth dilemma, once again. 


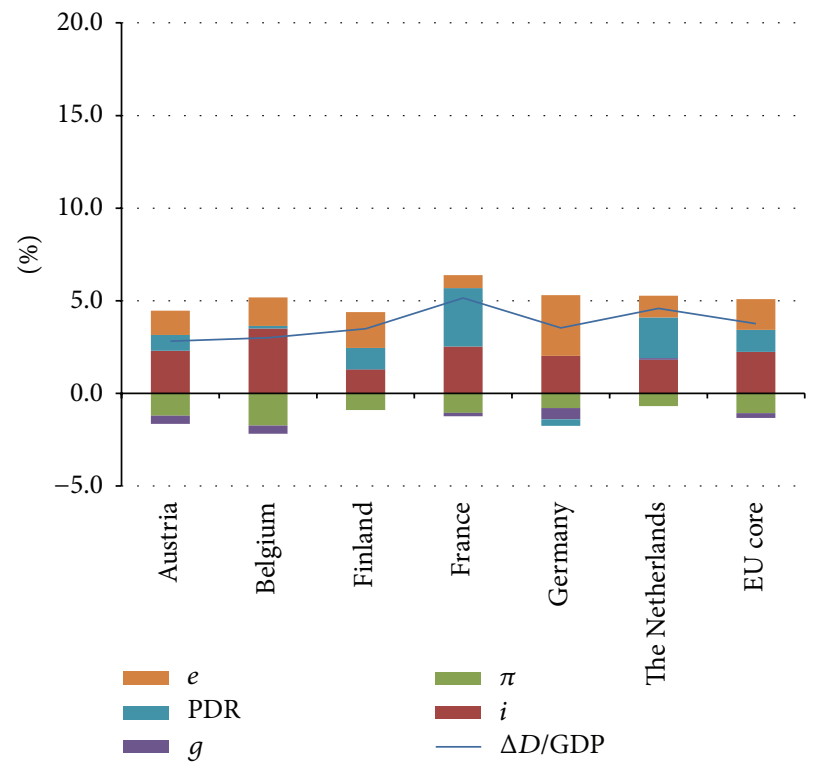

(a)

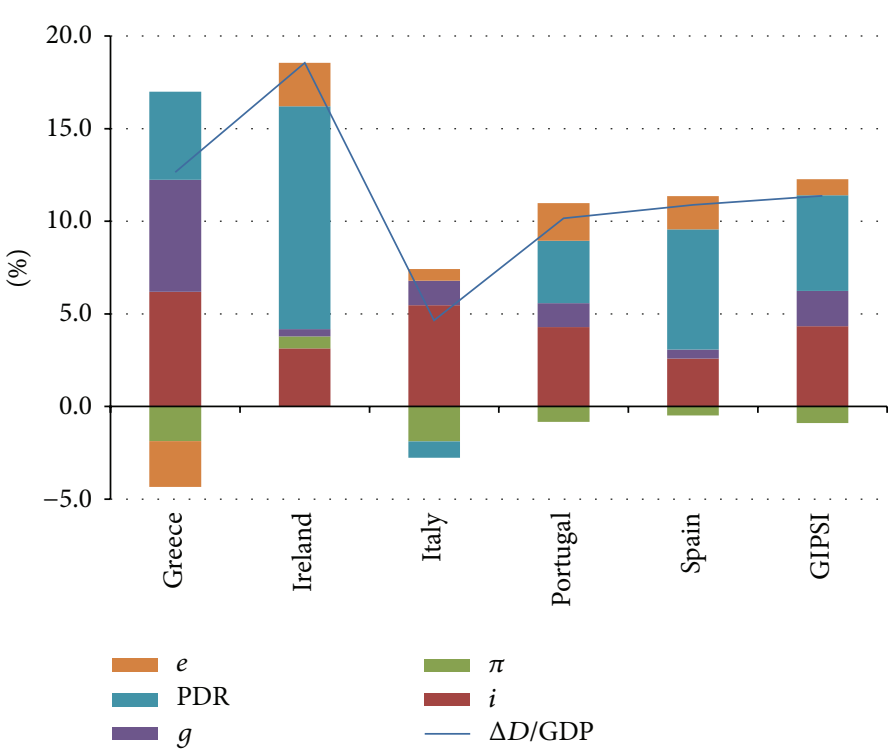

(b)

FIGURE 16: Debt dynamics, EU core versus GIPSI countries, period P2. Source: own elaboration.

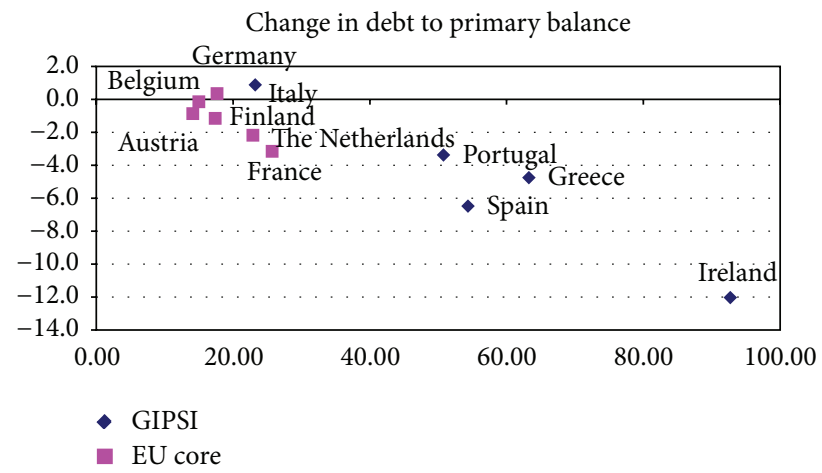

FIGURE 17: Change in debt to primary balance, P2 (2008-2012 $)$. Source: own elaboration.

Finally, the analysis of the relationship between inflation and debt ratios (see Figure 19) offers an interesting interpretation for the purposes of this paper.

There seems to be an apparent correlation between both variables: reducing average inflation by one percentage point would have raised debt ratios by $2.78 \%\left(R^{2}=58 \%\right)$. However, this effect might be only a consequence of Irish deflation. Indeed, when Ireland is excluded, goodness of fit falls to $R^{2}=$ 0.19 . We interpret this as an additional evidence of IMF's [3] result that the only clear association between inflation and debt ratios would be the difficulties deflation imposes for fiscal consolidation.

\section{Forecast}

We conduct a scenario analysis for fiscal consolidation by EU core and GIPSI countries. We consider two possible alternatives. First, European countries follow an "isolated strategy" - which seems to be the alternative European authorities are promoting-where core countries set zero deficit and low inflation as policy targets, whereas GIPSIs implement a strong fiscal consolidation and an internal devaluation that generates deflation. Second, a situation where core and peripheral countries set a "coordinated policy." Such coordinated policy would consist of core countries accepting a slightly higher inflation target, whereas GIPSI countries would focus on gradual consolidations and structural reforms in order to boost productivity and enhance their competitiveness. We wish to emphasize, the analysis below is a descriptive one that considers only the effects over sustainability of debt for a given set of growth scenarios; that is, we set growth as given, without considering the effect inflation, levels, and cost of debt would have over it.

We set a forecast scenario that spans 10 years, from 2013 to 2022, using average data for both groups of countries. For each group we consider eight $(2 \times 2 \times 2)$ possible scenarios that depend on their decisions on three macroeconomic variables. First, we analyze a debt stability goal versus a debt 


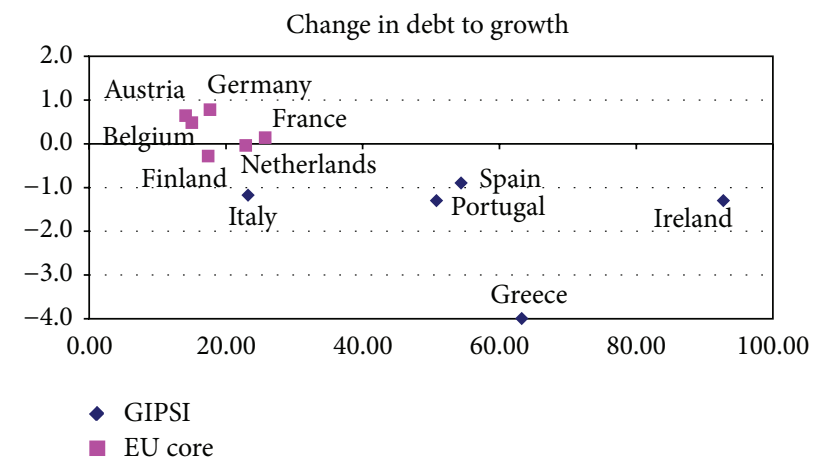

FIGURE 18: Change in debt to growth, P2 (2008-2012 $\left.{ }_{\mathrm{f}}\right)$. Source: own elaboration.

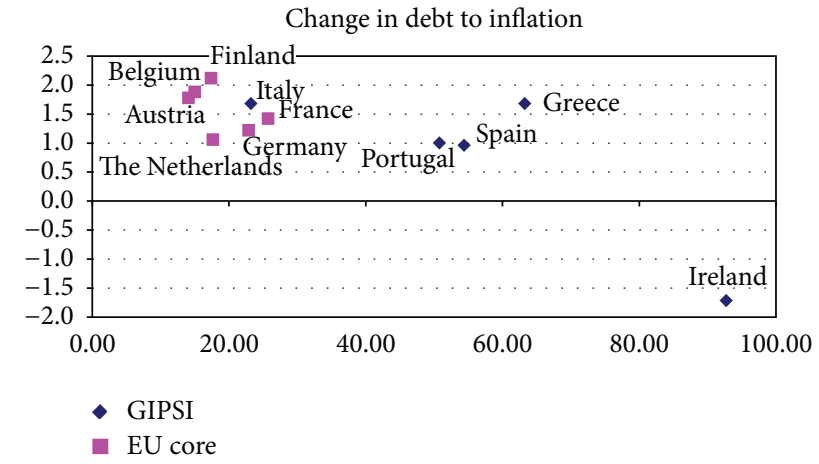

FIGURE 19: Change in debt to inflation, P2 (2008-2012 $)$. Source: own elaboration.

reduction scenario that leads debt down to the $60 \%$ level required in the Fiscal Compact within a reasonable period of time. Second, we compare the "isolated strategy" on inflation rate (below 2\% for EU core countries, deflation for peripheral countries) versus the "coordinated strategy" where GIPSIs set a low (but positive) inflation goal of $1.0 \%$, while core countries set it at $3.0 \%$, only one point above the usual ECB target. Third, for core countries we compare their performance under two alternative growth scenarios, growing at the last ten years average versus a "back to growth" scenario where they are able to grow at a pace like before the crisis. For GIPSI countries, instead, we focus on their cost of debt in order to compare their capacity to endure current market rates versus the necessity to reduce this cost-either involving a rescue plan or, hopefully, not.

For each scenario, we solve for the required PSR that ensures all objectives are achieved. Results for EU core are summarized in Figure 20.

In scenario 1 , in order to ensure debt stability at current levels (an average debt-to-GDP of about $80 \%$ by 2012), EU core countries could admit short primary deficits of $0.5 \%$ to $1.6 \%$, depending on the economic growth rate. However, would they accept a slightly higher inflation goal of about $3.0 \%$, primary deficits could be one percentage point larger. Alternatively, core countries may pursue a debt reduction strategy (scenario 2) in order to achieve the 60\% debt-to-GDP goal set in the Fiscal Compact by 2022. In this case, primary surpluses of about $0.5 \%$ to $1.8 \%$ would be required, with only the coordinated strategy under a "back to growth" scenario allowing for deficits. Again, primary deficits might be one percentage point larger if a higher inflation target is set.

To sum up, a coordinated strategy would only induce positive effects to EU core countries-at least if we agree that a one percent higher inflation target is not so troublesome. PSR target rates would be lower, hence easier to achieve in any case. This would also be equivalent to introducing a fiscal stimulus of at least $1 \%$ in EU core countries, which could go up to $3 \%$ would they be willing to postpone the debt reduction goal for some time at least until economic recovery of GIPSI countries is ensured. Simply compare the "coordinated strategy" (3\% inflation rate) under the debt stability scenario with the "isolated strategy" (inflation rate below $2 \%$ ) when core countries are trying to quickly reduce their debt levels.

If effects are positive for core countries, they would be even more benign to GIPSIs, as we may see in Figure 21.

Scenario 1 would be the base case. We set what we call an "average debt reduction" following IMF [3]. In the 26 episodes analyzed there, the median debt-to-GDP ratio was only 10 percentage points lower after 15 years. Hence, we assume the base scenario would be that where GIPSI countries set that average rate as a target (which implies a debt reduction from $125 \%$ to $118 \%$ within the ten years in our forecast period). We avoid setting a "debt stability" scenario similar to what we did for core countries, since it would leave debt levels constant at $125 \%$ for the next 10 years, clearly a dangerous 
EU core

Scenario debt stability, 2012-2022

Debt-to-GDP constant at $80 \%$

r.r. $=0 \%$ annual debt reduction rate

Int. rate debt, $i=2.5 \%$

\begin{tabular}{|ll|l|l|}
\cline { 3 - 4 } \multicolumn{1}{c|}{} & & $\begin{array}{c}g_{1}=10 \mathrm{y} \text { average } \\
1.5 \%\end{array}$ & $\begin{array}{c}g_{2}=\text { "back to growth" } \\
3.0 \%\end{array}$ \\
\hline$\pi_{1}=10$ y average & $1.6 \%$ & PSR $=-0.5 \%$ & PSR $=-1.6 \%$ \\
\hline$\pi_{2}=$ GIPSI $+2 \%$ & $3.0 \%$ & PSR $=-1.6 \%$ & PSR $=-2.7 \%$ \\
\hline
\end{tabular}

2 Scenario 10 y fiscal compact debt reduction, 2012-2022

Debt-to-GDP from 80\% 2012 to $60 \% 2022$

r.r. $=-2.8 \%$ annual debt reduction rate

Int. rate debt, $i=2.5 \%$

\begin{tabular}{|ll|c|c|}
\cline { 3 - 4 } \multicolumn{1}{c|}{} & & $\begin{array}{c}g_{1}=10 \text { y average } \\
1.5 \%\end{array}$ & $\begin{array}{c}g_{2}=\text { "back to growth" } \\
3.0 \%\end{array}$ \\
\hline$\pi_{1}=10$ y average & $1.6 \%$ & PSR $=(1.8 \%$ to $1.4 \%)$ & PSR $=(0.6 \%$ to $0.5 \%)$ \\
\hline$\pi_{2}=$ GIPSI $+2 \%$ & $3.0 \%$ & PSR $=(0.7 \%$ to $0.5 \%)$ & PSR $=(-0.5 \%$ to $-0.4 \%)$ \\
\hline
\end{tabular}

FIgUre 20: Policy alternatives for EU core countries. Source: own elaboration.

GIPSI

1 Scenario average debt reduction (IMF 2012c), 2012-2022

Debt-to-GDP from 125\% 2012 to $118 \% 2022$

r.r. $=-0.55 \%$ annual debt reduction rate

Growth rate, $g=1.5 \%$

\begin{tabular}{|l|c|c|}
\cline { 2 - 3 } \multicolumn{1}{c|}{} & $\begin{array}{c}i_{1}=350 \mathrm{bp} \text { risk pr. } \\
6.0 \%\end{array}$ & $\begin{array}{c}i_{2}=100 \mathrm{bp} \text { risk pr. } \\
3.5 \%\end{array}$ \\
\hline$\pi_{1}=$ "low inflation" $1.0 \%$ & PSR $=(4.9 \%$ to $4.7 \%)$ & PSR $=(1.9 \%$ to $1.8 \%)$ \\
\hline$\pi_{2}=$ "deflation" $3.0 \%$ & PSR $=(10.3 \%$ to $9.8 \%)$ & PSR $=(7.1 \%$ to $6.7 \%)$ \\
\hline
\end{tabular}

2 Scenario strongest path to recovery, 2012-2022

Debt-to-GDP from 125\% 2012 to $98 \% 2022$ (60\% debt in 30 y)

r.r. $=-2.4 \%$ annual debt reduction rate

Growth rate, $g=3.0 \%$

\begin{tabular}{|l|c|c|}
\cline { 2 - 3 } \multicolumn{1}{c|}{} & $\begin{array}{c}i_{1}=350 \text { bp risk pr. } \\
6.0 \%\end{array}$ & $\begin{array}{c}i_{2}=100 \text { bp risk pr. } \\
3.5 \%\end{array}$ \\
\hline$\pi_{1}=$ "low inflation" $1.0 \%$ & PSR $=(5.4 \%$ to $4.3 \%)$ & PSR $=(2.4 \%$ to $1.9 \%)$ \\
\hline$\pi_{2}=$ "deflation" $3.0 \%$ & PSR $=(10.6 \%$ to $8.5 \%)$ & $\operatorname{PSR}=(7.5 \%$ to $6.0 \%)$ \\
\hline
\end{tabular}

FIgURE 21: Policy alternatives for GIPSI countries. Source: own elaboration.

policy. We set a growth rate of $1.5 \%$-equivalent to the EU core base case but ambitious for GIPSIs in the short run given current conditions-and consider the effects of the isolated versus coordinated policies. Finally, we consider as well the effects of market rates over the sustainability of debt: (i) what if GIPSI countries have to face market rates of $6 \%, 350 \mathrm{bp}$. above core countries' cost of debt (a rate representative of what Italy, Ireland, and Spain have been paying recently); (ii) what if they face a cost of debt of 3.5\% (100 bp. above core countries' cost of debt), a rate that could either mean all GIPSI countries were rescued-indeed $3.5 \%$ is about the rate agreed on Greek, Irish, and Portuguese bailouts-or that they have succeeded in restoring market confidence.

Results show how harmful deflation would be. According to Bencek and Klodt's [27] empirical assessment, it is extremely difficult for a country to prevent debt dynamics to become explosive when the required PSR reaches a critical level of more than 5\%. In scenario 1, required PSRs would be even more than $10 \%$ if peripheral countries face deflation, simply unfeasible. (Just to compare, the best PSR of all countries in the dataset was 4.65\%, by Finland in 2007.) Even if market rates go down to more sustainable risk premia of about 100 basis points, required PSRs would be well above $5 \%$. (Indeed it would be worst considering the effects that the consolidation might have over growth [3].) A low inflation strategy, instead, would be effective as long as market rates were moderate. For market rates about $6 \%$, required PSRs would be on the very edge of the $5 \%$ threshold, but things improve the lower the rates from there. For a cost of debt of $3.5 \%$, required PSRs would be about $2 \%$. Figure 22 provides a 


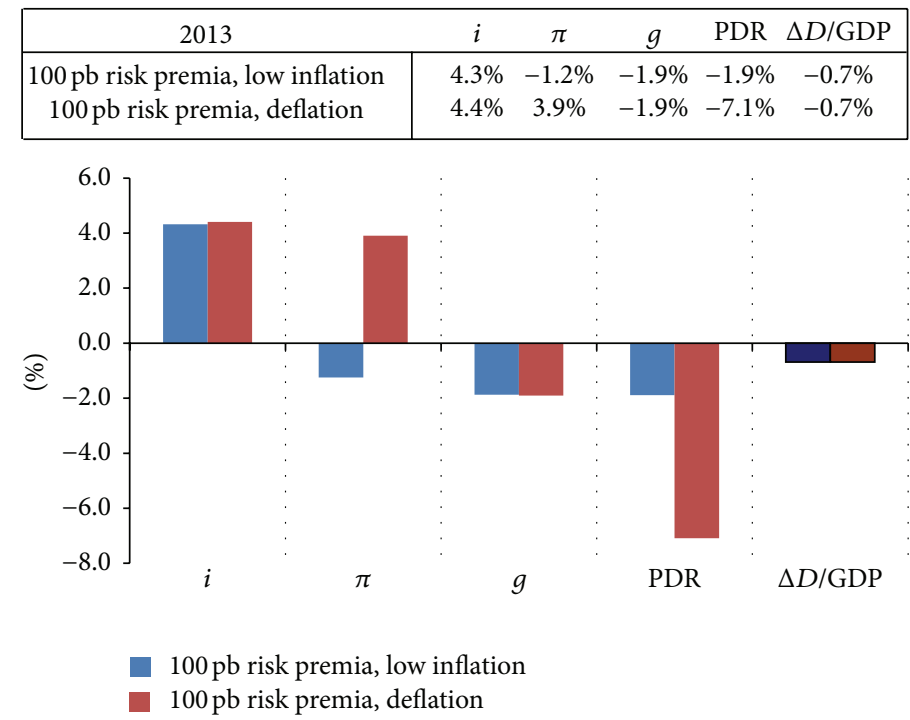

FIGURE 22: GIPSI countries scenario 1: isolated versus coordinated strategy. Source: own elaboration.

clear picture of this tradeoff between inflation and primary deficits by comparing the contribution of each factor to the dynamics of debt under the isolated and coordinated strategies for a risk premium of 100 basis points.

Scenario 2 in Figure 21 sets a more ambitious target: GIPSI countries would reduce their debt down to the $60 \%$ level required in the Fiscal Compact within a reasonable period of time. Since this scenario would be unfeasible under a low growth scenario, we set growth at $3 \%$. Hence, we may interpret scenario 2 not as a policy choice but as a consequence of the environment: if GIPSI countries are "only" able to grow at $1.5 \%$ per year, they should aim to reduce debt at the average rate (scenario 1); if they are able to grow faster, then a more ambitious target would be available (scenario 2). This would take 30 years for an annually compounded debt reduction rate of $-2.4 \%$ (versus a reduction rate of $-0.55 \%$ in scenario 1 ).

Results are very similar: required PSRs would be more than $10 \%(6 \%)$ if peripheral countries face deflation and a risk premium of $350 \mathrm{bp}$. (100 bp.). A low inflation strategy, instead, would be effective: required PSRs about the 5\% threshold for market rates about $6 \%$, and about $2 \%$ for a cost of debt of $3.5 \%$. That is, results are quite similar to those in scenario 1 , but we should remember that scenario 2 requires GIPSI countries to grow at double speed. Again, Figure 23 evidences the inflation-PDR tradeoff by comparing the isolated and coordinated strategies for a risk premia of 100 basis points.

Finally, we have considered excluding Greece from our analysis. Greece might be regarded as an outlier inside the GIPSI countries. Current debt level is twice that of Spain, for instance, and despite two consecutive rescue plans and one debt-restructuring episode, authorities seem unable to stabilize it. At the time of writing this paper, European authorities and the IMF were negotiating the possibility of an additional debt cut in order to ensure that the objective of a
$120 \%$ debt-to-GDP ratio by 2020 is still achievable. Indeed, there is an increasing feeling among the academics that the resolution of the Eurozone crisis will eventually require a debt restructuring for European countries, perhaps not only Greece (see, for instance, $[28,29]$ ).

Following this, scenario $2^{\prime}$ in Figure 24 would be equivalent to scenario 2 by all means except we are not considering Greece in the GIPSI group.

We may see things improve only a little. The best outcome is that peripheral countries would be able to reduce debt down to $60 \%$ in 25 years, rather than 30 . Required PSR under a low inflation scenario would be slightly better than including Greece, but deflation would be destructive either way.

\section{Concluding Remarks}

We have seen how internal devaluation might only make fiscal consolidation for GIPSI countries even harder to achieve. There is a broad consensus that the institutional design of the Eurozone was a major factor behind the sovereign debt crisis. We should not repeat this mistake again, imposing GIPSI countries an economic policy that exposes them to the risks of deflation.

The necessity of correcting fiscal imbalances and reducing public debt is clear, but the debate is bitter regarding how to achieve that goal. Some authors have worried that governments will use inflation in order to achieve fiscal solvency, while others suggest on the contrary that accepting a higher inflation target would be an effective strategy. This paper contributes to the debate with an alternative that may satisfy both views: setting a coordinated policy among Eurozone members, where EU core countries accept a 3\% target for inflation and reduce the pace of their fiscal consolidation, while GIPSI countries focus on fiscal consolidation with a 


\begin{tabular}{|c|c|c|c|c|c|}
\hline 2013 & $i$ & $\pi$ & $g$ & PDR & $\Delta D / G D P$ \\
\hline $100 \mathrm{pb}$ risk premium, low inflation & $4.3 \%$ & $-1.2 \%$ & $-3.7 \%$ & $-2.4 \%$ & $-3.0 \%$ \\
\hline $100 \mathrm{pb}$ risk premium, deflation & $4.4 \%$ & $3.9 \%$ & $-3.8 \%$ & $-7.5 \%$ & $-3.0 \%$ \\
\hline
\end{tabular}

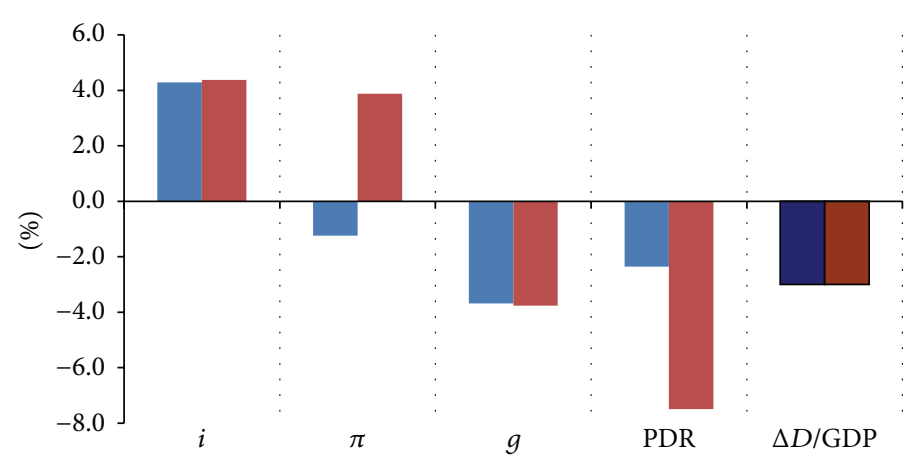

$100 \mathrm{pb}$ risk premium, low inflation

$100 \mathrm{pb}$ risk premium, deflation

FIGURE 23: GIPSI countries scenario 2: isolated versus coordinated strategy. Source: own elaboration.

GIPSI w/o Greece

$2^{\prime}$ Scenario strongest path to recovery, 2012-2022

Debt-to-GDP from $113 \% 2012$ to $88 \% 2022$ (60\% debt in $25 \mathrm{y}$ )

r.r. $=-2.5 \%$ annual debt reduction rate

Growth rate, $g=3.0 \%$

\begin{tabular}{|l|c|c|}
\cline { 2 - 3 } \multicolumn{1}{c|}{} & $\begin{array}{c}i_{1}=350 \text { bp risk pr. } \\
6.0 \%\end{array}$ & $\begin{array}{c}i_{2}=100 \text { bp risk pr. } \\
3.5 \%\end{array}$ \\
\hline$\pi_{1}=$ "low inflation" $1.0 \%$ & $\mathrm{PSR}=(5.0 \%$ to $4.0 \%)$ & $\mathrm{PSR}=(2.2 \%$ to $1.8 \%)$ \\
\hline$\pi_{2}=$ "deflation" $3.0 \%$ & $\mathrm{PSR}=(9.7 \%$ to $7.7 \%)$ & $\mathrm{PSR}=(6.9 \%$ to $5.5 \%)$ \\
\hline
\end{tabular}

FIGURE 24: Policy alternatives for GIPSI countries without Greece. Source: own elaboration.

low (but positive) level of inflation. This would on one hand avoid the perils of deflation on GIPSI countries, while on the other it requires an inflation goal to EU core members only one percentage point above the ECB's target.

In Section 4 we analyzed the main drivers of debt dynamics for peripheral versus core countries in the Eurozone, before and after the triggering of the crisis. The main results observed supported the view that GIPSI countries should focus on implementing a fiscal consolidation that does not damage growth, while deflation should be avoided. In Section 5 we provided a scenario analysis to compare the effectiveness of the coordinated policy versus an "isolated strategy" where GIPSI countries focus mainly on internal devaluation of wages and prices. We show the coordinated policy might be a better option as it (i) increases the competitiveness of GIPSI countries while avoiding the risks of deflation, (ii) ensures stability of debt for both groups without requiring an excessive inflation target from EU core, and (iii) introduces the possibility for a fiscal stimulus that boosts demand in core-and, indirectly, in peripheral countries. This combined policy would set a more suitable scenario for fiscal consolidation of GIPSIs to succeed, helping to solve the euro crisis and hence benefiting both peripheral and core countries.

\section{Appendix}

Ireland accepted a bailout on November 21, 2010, consisting of 85 billion eur- 67.5 bn by IMF (33\%) and EU (66\%), 17.5 bn of Ireland's own reserves and pensions-at an initial cost of about 5.8\% (IMF Press Release no. 10/496 and Irish Government statement, available at http://www.guardian.co.uk/ business/ireland-business-blog-with-lisa-ocarroll/2010/nov/ 28/ireland-bailout-full-full-government-statement). Portugal accepted a bailout on May 16, 2011, of 78 billion eur granted by $\operatorname{IMF}(33 \%)$ and $\mathrm{EU}(66 \%)$, at an initial cost of about 5.5\% (IMF Press Release no. 11/190 and Diário de Notícias, http://economico.sapo.pt/noticias/o-emprestimo-a-portugal-e-porque-e-que-325-55_118094.html). Later, by July 2011, European Authorities [30] agreed that the EFSF lending rates and maturities agreed upon for Greece would also apply Portugal and Ireland. This way, interest rates on the EU share of the three bailouts dropped from around 6\% to $3.5 \%$ to $4 \%$. The Greek case is far more complex. In May 2010, Greece accepted a first bailout of 110 billion eur-IMF ( $30 \mathrm{bn}, 27 \%)$ and $\mathrm{EU}(80 \mathrm{bn}, 73 \%)$ at an initial cost of about $5 \%$ the EU funds and $3.5 \%$ to $4.5 \%$ the IMF (IMF Press Release no. 10/187) later reduced to $3.5 \%$ to $4 \%$ as mentioned. By February 2012, Greece received a second bailout of 130 
billion eur, granted by the Troika (EC, IMF, and ECB) at a cost of $3.5 \%$ that included a debt restructuring of $53.5 \%$ over 206 billion eur of Greek debt [26]. By the time of writing this paper, Greek finances received additional support following an agreement between IMF and the Eurogroup on November, 26th. The initiatives include Greek debt buybacks, reduction of interest rates, significant extension of Greek Loan Facility and EFSF maturities, and the deferral of EFSF interest rate payments (IMF Press Release no. 12/458). According to all these pieces of information, we have used the following data as a proxy for the cost of debt of Greece, Ireland, and Portugal between 2010 and 2012: year 2010, 5.0\% for Greece, market rates for Ireland and Portugal; year 2011, $4.5 \%$ for Greece and Ireland, 7.0\% for Portugal (as the rescue plan for Portugal came at about mid-year); year 2012, 4.0\% for all three countries.)

\section{Acknowledgment}

The authors wish to thank Marcos Vizcaíno for technical assistance.

\section{References}

[1] International Monetary Fund, "Global financial stability report," October 2012, http://www.imf.org/External/Pubs/FT/ GFSR/2012/02/pdf/text.pdf.

[2] A. Abbas, O. Basdevant, S. Eble et al., "Strategies for fiscal consolidation in the post-crisis world," Fiscal Affairs Department Paper 10/04, International Monetary Fund, Washington, DC, USA, 2010.

[3] International Monetary Fund, "World economic outlook 2012," October 2012, http://www.imf.org/external/pubs/ft/weo/2012/ 02/pdf/text.pdf.

[4] O. Blanchard and D. Leigh, "Growth forecast errors and fiscal multipliers," IMF Working Paper 13/1, International Monetary Fund, Washington, DC, USA, 2013.

[5] P. R. Lane, “The European sovereign debt crisis," Journal of Economic Perspectives, vol. 26, no. 3, pp. 49-68, 2012.

[6] S. Schmitt-Grohé and M. Uribe, "The case for temporary inflation in the Eurozone," CEPR Discussion Paper 9133, 2012.

[7] J. C. Díez, Devaluación y Sostenibilidad de Deuda, El País, 2012.

[8] M. Antelo and D. Peón, "Fiscal consolidation and the sustainability of public debt in the GIPSI countries," Unpublished manuscript.

[9] International Monetary Fund, "Fiscal monitor," October 2012, http://www.imf.org/external/pubs/ft/fm/2012/02/pdf/fm1202 .pdf.

[10] J. Caruana and S. Avdjiev, "Sovereign creditworthiness and financial stability: an international perspective," Banque de France Financial Stability Review, no. 16, pp. 71-85, 2012.

[11] C. M. Reinhart and K. S. Rogoff, "From financial crash to debt crisis," American Economic Review, vol. 101, no. 5, pp. 1676-1706, 2011.

[12] A. Mody and D. Sandri, "The eurozone crisis: how banks and sovereigns came to be joined at the hip," Economic Policy, vol. 27, no. 70, pp. 199-230, 2012.

[13] W. Buiter, G. Corsetti, and N. Roubini, "Excessive deficits: sense and nonsense in the treaty of maastrich," Economic Policy, vol. 8 , no. 16 , pp. $57-100,1993$.
[14] C. M. Reinhart, V. R. Reinhart, and K. S. Rogoff, "Public debt overhangs: advanced-economy episodes since 1800," Journal of Economic Perspectives, vol. 26, no. 3, pp. 69-86, 2012.

[15] C. M. Reinhart and K. S. Rogoff, "Growth in a time of debt," American Economic Review, vol. 100, no. 2, pp. 573-578, 2010.

[16] U. Panizza and A. F. Presbitero, "Public debt and economic growth: is there a causal effect?” MoFiR Working Paper 65, 2012.

[17] T. Herndon, M. Ash, and R. Pollin, "Does high public debt consistently stifle economic growth? A critique of Reinhart and Rogoff," Amherst Working Paper 322, Public Economy Research Institute at University of Massachusetts, 2013.

[18] E. Faraglia, A. Marcet, R. Oikonomou, and A. Scott, "The impact of debt levels and debt maturity on inflation," CEPR Discussion Paper 9257, 2012.

[19] K. S. Rogoff, The Bullets Yet to be Fired to Stop the Crisis, Financial Times, 2011.

[20] P. Krugman, Internal Devaluation, Inflation, and the Euro (Wonkish), New York Times, 2012.

[21] J. E. Stiglitz, The Price of Inequality: How Today's Divided Society Endangers Our Future, W. W. Norton \& Company, 2012.

[22] R. Rajan, "Is inflation the answer?" Project Syndicate, 2011.

[23] J. Andrés, Debe Europa Tolerar una Inflación Más Elevada, Fedea, 2012.

[24] J. Aizenman and N. Marion, "Using inflation to erode the US public debt," NBER Working Paper 15562, 2009.

[25] European Commission, "Declaration on a concerted European action plan of the Euro area countries," 2008, http://ec. europa.eu/economy_finance/publications/publication13260_en .pdf.

[26] Council of the European Union, "Eurogroup statement," February 2012, http://www.consilium.europa.eu/uedocs/cms _data/docs/pressdata/en/ecofin/128075.pdf.

[27] D. Bencek and H. Klodt, "The kiel institute barometer of public debt-institut für weltwirtschaft," 2011, http://www.ifwkiel.de/think-tank/policy-support/The-Kiel-Institute-Barometer-of-Public-Debt\%20.

[28] C. Wyplosz, Fiscal Discipline in the Monetary Union, VoxEu, 2012.

[29] U. S. Das, M. G. Papaioannou, and C. Trebesch, Restructuring Sovereign Debt, 1950-2010: From Process to Outcomes, VoxEu, 2012.

[30] Council of the European Union, Statement by the Heads of State or Government of the Euro Area and EU Institutions, Brussels, Belgium, 2011. 


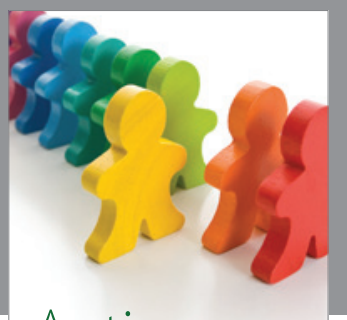

Autism

Research and Treatment
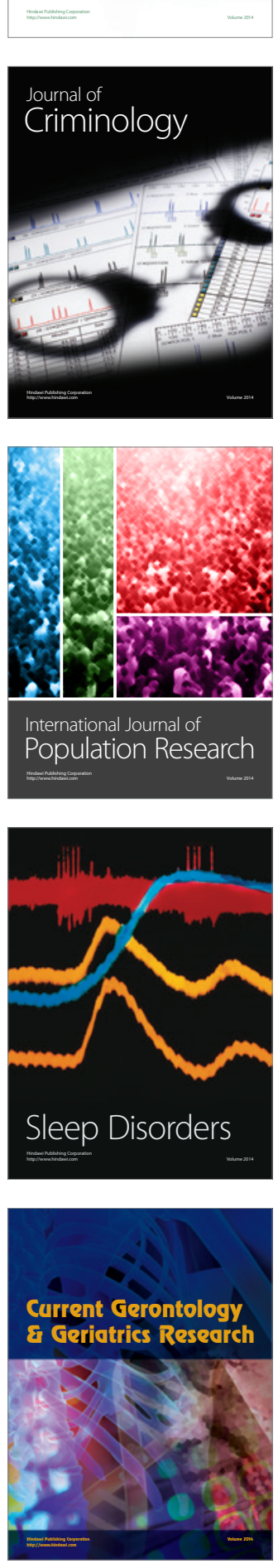
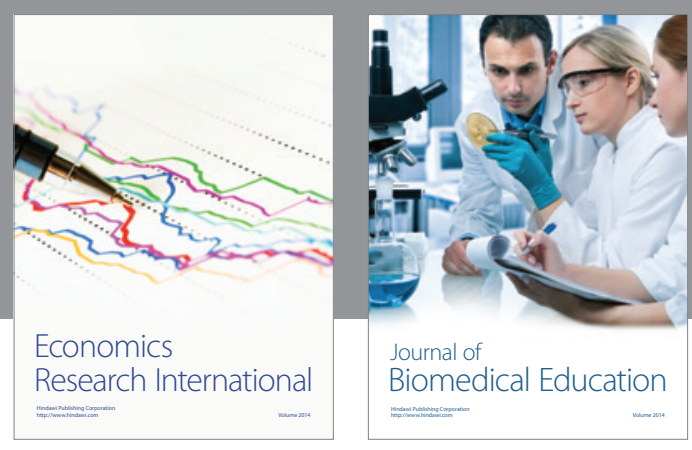

Journal of

Biomedical Education

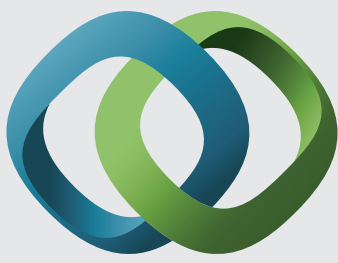

\section{Hindawi}

Submit your manuscripts at

http://www.hindawi.com
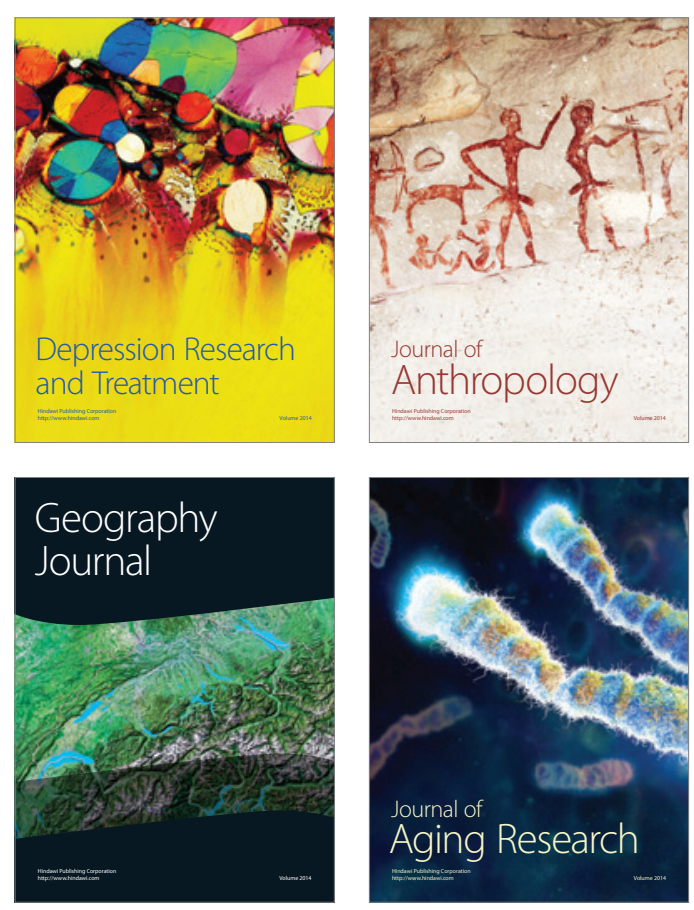

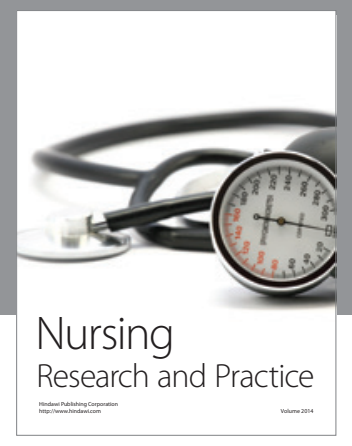

Nursing

Research and Practice

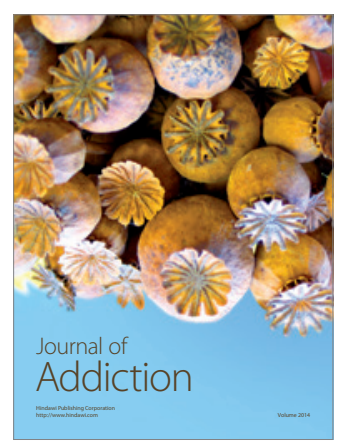

Child Development

Research

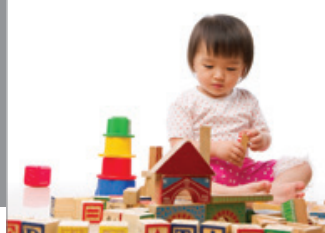

迥
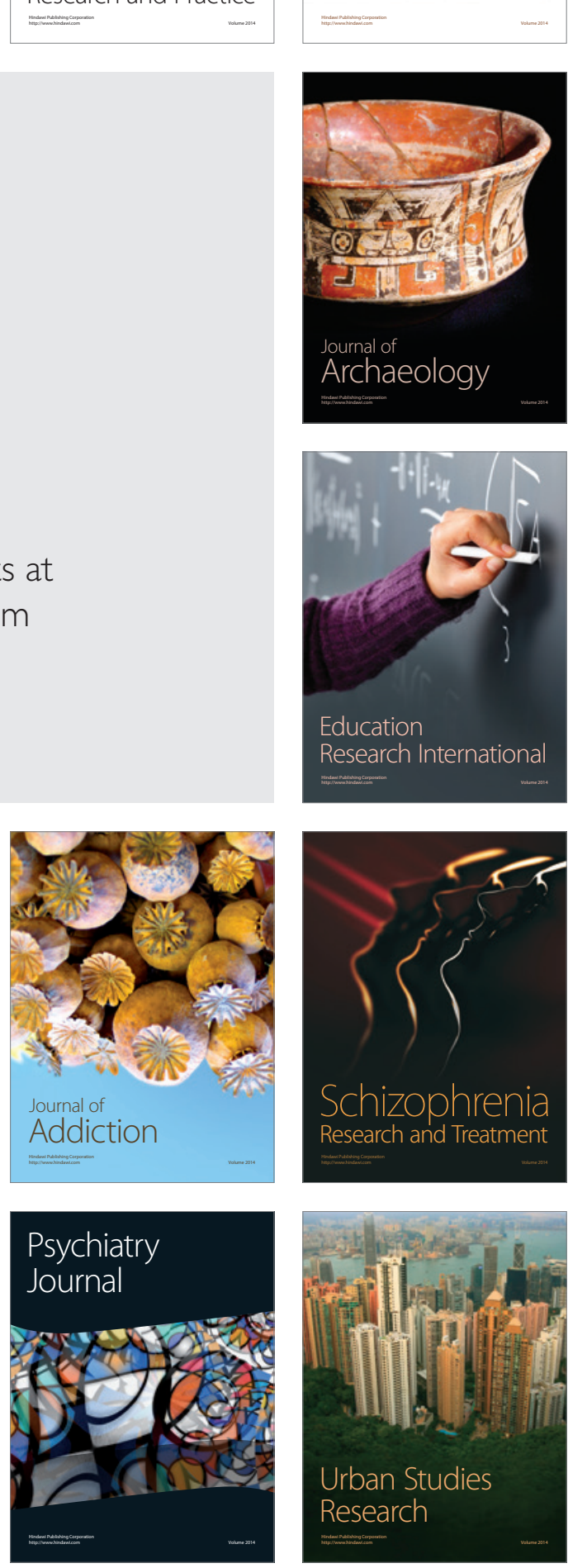